\title{
A magyarországi mikro-, kis- és középvállalkozások fizetési szokásainak elemzése - fókuszban a készpénzhasználat*
}

\author{
Belházyné Illés Ágnes - Végső Tamás - Bódi-Schubert Anikó
}

Tanulmányunkban a magyarországi mikro-, kis- és középvállalkozások készpénzhasználatát, valamint annak föbb okait vizsgáljuk egy 1000 elemszámú, vállalatvezetökből álló mintán végrehajtott kérdőíves felmérés adatait elemezve. Ehhez kapcsolódóan vizsgáljuk a vállalkozások fizetési szokásait és pénzintézeti kapcsolatait, az üzleti bizalomhiány mértékét a hazai vállalati szférában, valamint a készpénzhasználat visszaszoritásának lehetséges eszközeit. Ahol módunkban áll, eredményeinket összehasonlítjuk a hasonló fókuszú, korábban publikált magyar, illetve külföldi kutatások tanulságaival. Legfontosabb következtetéseink szerint mind a KKV-szektorban, mind pedig a mikrovállalkozások körében egyértelmüen a banki átutalás a legelterjedtebb fizetési mód, azonban a készpénzhasználat aránya is magas, és nem mutat csökkenő tendenciát. Pozitiv változás figyelhető meg viszont a fizetési fegyelem és az üzleti bizalom terén. A magyar vállalkozások lojálisak számlavezető bankjaikhoz, és alapvetően nyitottak az elektronikus fizetési megoldások iránt, ugyanakkor igen érzékenyek annak költségeire.

Journal of Economic Literature (JEL) kódok: G30, G32, L14

Kulcsszavak: KKV-szektor, mikrovállalkozások, készpénzhasználat, fizetési szokások, üzleti bizalom, hitelintézeti preferenciák, elektronikus fizetési megoldások

\section{Bevezetés}

A KSH (2017) adatai szerint 2016-ban Magyarországon összesen 687698 mikro-, kis- és középvállalkozás működött. Ez a szektor adja mennyiségileg a hazai vállalkozások 99,1 százalékát, valamint foglalkoztatást biztosít a vállalkozási szférában dolgozók több mint kétharmadának. Emellett a hozzáadott érték 43 százalékával, valamint a nettó árbevétel 42 százalékával járul hozzá a magyarországi vállalkozások összteljesítményéhez. Egyértelmű tehát, hogy a KKV-szektor vállalatai kiemelt

\footnotetext{
* A jelen kiadványban megjelenő írások a szerzők nézeteit tartalmazzák, ami nem feltétlenül egyezik a Magyar Nemzeti Bank hivatalos álláspontjával.

Belházyné Illés Ágnes a Magyar Nemzeti Bank vezető készpénzpolitikai szakértője. E-mail: belhazynea@mnb.hu Végső Tamás a Magyar Nemzeti Bank junior készpénzpolitikai szakértője. E-mail: vegsot@mnb.hu Bódi-Schubert Anikó a Magyar Nemzeti Bank föosztályvezetője. E-mail: schuberta@mnb.hu
}

A magyar nyelvű kézirat első változata 2018. február 26-án érkezett szerkesztőségünkbe.

DOI: http://doi.org/10.25201/HSZ.17.4.5394 
szerepet játszanak a magyar gazdaságban és ezáltal a pénzforgalomban is. Fizetési gyakorlatuk, készpénzhez való hozzáállásuk hatással lehet a teljes társadalom szokásaira, különösen, mivel túlnyomó többségük a szolgáltatási ágazatban tevékenykedik. A vállalkozások túlzott mértékű készpénzhasználata csökkenti a szektor transzparenciáját, nehezebben ellenőrizhetővé teszi múködésüket, így gazdasági szempontból nagy jelentőséggel bírhat a jelenség okainak felderítése, fizetési szokásaik átfogóbb megismerése, valamint annak vizsgálata, mi motiválná ezen szereplőket az elektronikus fizetési megoldások szélesebb körủ igénybevételére.

Tanulmányunk elsődleges célja annak vizsgálata, hogy a magyarországi mikro-, kisés középvállalatok üzleti tranzakcióiban milyen szerepe van a készpénzfizetésnek, és mely tényezők jelentik a vállalatok számára az alapvető motivációt a készpénzhasználatra. Törekszünk emellett annak megértésére, hogy a vállalkozások közötti (B2B) tranzakciókban létrejövő fizetések milyen üzleti környezetben zajlanak, azaz milyen fizetési módok és határidők, fizetési fegyelem és pénzügyi menedzsment tudatosság jellemzi azokat. Ez utóbbi szempontot azért tartjuk különösen fontosnak a vizsgált szektor esetén, mert a lejárt vagy esetleg behajthatatlan vevői követelések okozhatnak olyan komoly likviditási problémát a vállalati múködésben, ami súlyos esetben akár növekedési korlátot is jelenthet, vagy a vállalkozás múködőképességét is veszélyeztetheti. Részben az előző ponttal összefüggésben felmérjük továbbá az érintett vállalkozások pénzintézeti szokásait, illetve számlavezető hitelintézetükkel szemben támasztott igényeit, preferenciáit is.

Kutatásunkban részben megismételtük a 2013-ban elvégzett hasonló fókuszú vizsgálatot, melynek célja a készpénz szerepének felmérése volt a hazai KKV-szektor vállalatai között létrejött tranzakciók lebonyolításában, eredményeit pedig Bódi-Schubert (2014) tanulmánya foglalta össze. Mivel az akkori kutatás közvetlenül a gazdasági válságot követő, kilábalási időszakban zajlott, így a szerző kiemelten foglalkozott azzal, hogy a vállalkozások közötti üzleti bizalom mértéke befolyásolhatja-e a gyakorlatban a fizetési módok közötti választást. Tekintettel arra, hogy a gazdasági környezet az elmúlt 5 év során jelentősen megváltozott pozitív irányban, így a 2017-es adatfelvétel alkalmával erre a dimenzióra nem fektettünk külön hangsúlyt.

A korábbi, 2013-as kutatás csak a kis- és középvállalkozások készpénzhasználati szokásait vizsgálta. Mivel azonban ezek száma csupán töredéke a mikrovállalkozásokénak (a KSH 2017 adatai szerint 2016-ban Magyarországon 649733 mikrovállalkozás mellett 37965 kis- és középvállalkozás múködött), valamint feltételezésünk szerint a mikrovállalkozásokra a kis összegú tranzakciók és a költségérzékenység miatt kiemelten jellemző a rendszeres készpénzhasználat, így jelen kutatásunkba ezt a szektort is bevontunk. Felmérésünkben azért nem fókuszáltunk a nagyvállalati szektorra, mivel ott az éves beszámolók adatai alapján jóval kevésbé jellemző a készpénz használata, valamint a nagyvállalatok vevő- és beszállító-értékelési gyakorlata, likviditásmenedzsmentje is szinte minden esetben professzionálisnak tekinthető. 


\section{Kutatásmódszertan}

A 2017-es kutatás során - a 2013-as felméréshez hasonlóan - kvantitatív és kvalitatív eszközökkel vizsgáltuk a hazai kis- és középvállalkozások (azon belül külön a mikrovállalkozások) körében a vevői és beszállítói pozícióban alkalmazott fizetési szokások és a készpénzhasználat összefüggéseit. Az adatfelvételt az MNB megbízásából a Századvég Politikai Iskola Alapítvány végezte.

A kvalitatív szakaszban 10 vállalattal (6 KKV, 4 mikrovállalkozás) készült személyes interjú. A kvantitatív szakaszban pedig az effektív mintaelemszám a mikro- és a KKV-szektor esetén is 500-500 - tevékenységi körük alapján heterogén - hazai vállalkozást tett ki. A kérdőív lekérdezése kizárólag telefonos interjúkkal történt, a feltett kérdések a Mellékletben olvashatóak. A 2017-es és a 2013-as felmérésben részt vett vállalkozásokat tartalmazó kvantitatív minták tevékenységi körök szerinti összetételét az 1. ábra mutatja, a hazai vállalkozások KSH-adatokon alapuló tényleges arányaitól vett eltérést az adatbázisokban súlyozással korrigáltuk. Az egyes tevékenységi ágazatokon belül a minta nem tekinthető reprezentatívnak, valamint az ez alapján azonos csoportokba tartozó válaszadók száma is alacsonynak mondható, így a kvantitatív eredmények csak korlátozottan alkalmasak a vállalkozások fő tevékenysége és fizetési, készpénzhasználati szokásai közötti összefüggések vizsgálatára.

A megkérdezett vállalkozásokat képviselő válaszadók mindegyike tulajdonos/ügyvezető volt a mikrovállalkozások esetében, míg a kis- és középvállalatoknál a válaszadók 26,8 százaléka tulajdonosi, 46,7 százaléka ügyvezetői/menedzseri, 26,6 százaléka pedig pénzügyi/gazdálkodási vezetői pozícióból válaszolta meg a kérdéseket. A kérdőívek mindkét vállalattípusnál a szürő és a vállalkozások általános jellemzőire (az alkalmazottak számára, az éves nettó árbevételre) vonatkozó kérdésekkel kezdődtek, ezt követően először a beszállítói, majd a vevői kapcsolatokra, valamint a munkabér és a közüzemi díjak kifizetésére jellemző fizetési szokások, továbbá a készpénzhasználat motivációinak feltérképezése következett. A kérdőívek záró kérdésblokkja a fizetési forgalmat befolyásoló adminisztrativ intézkedések hatásaival, a készpénzhasználat csökkentése irányába ható ösztönzőkkel, valamint a vállalkozások hitelintézeti kapcsolataival (bankválasztás, bankváltás szempontjaival) foglalkozott. 


\section{1. ábra \\ A kutatásban részt vett vállalkozásokat tartalmazó minták megoszlása a vállalkozások fő tevékenységi köre alapján, valamint a KSH adatai szerinti valós megoszlás (\%)}

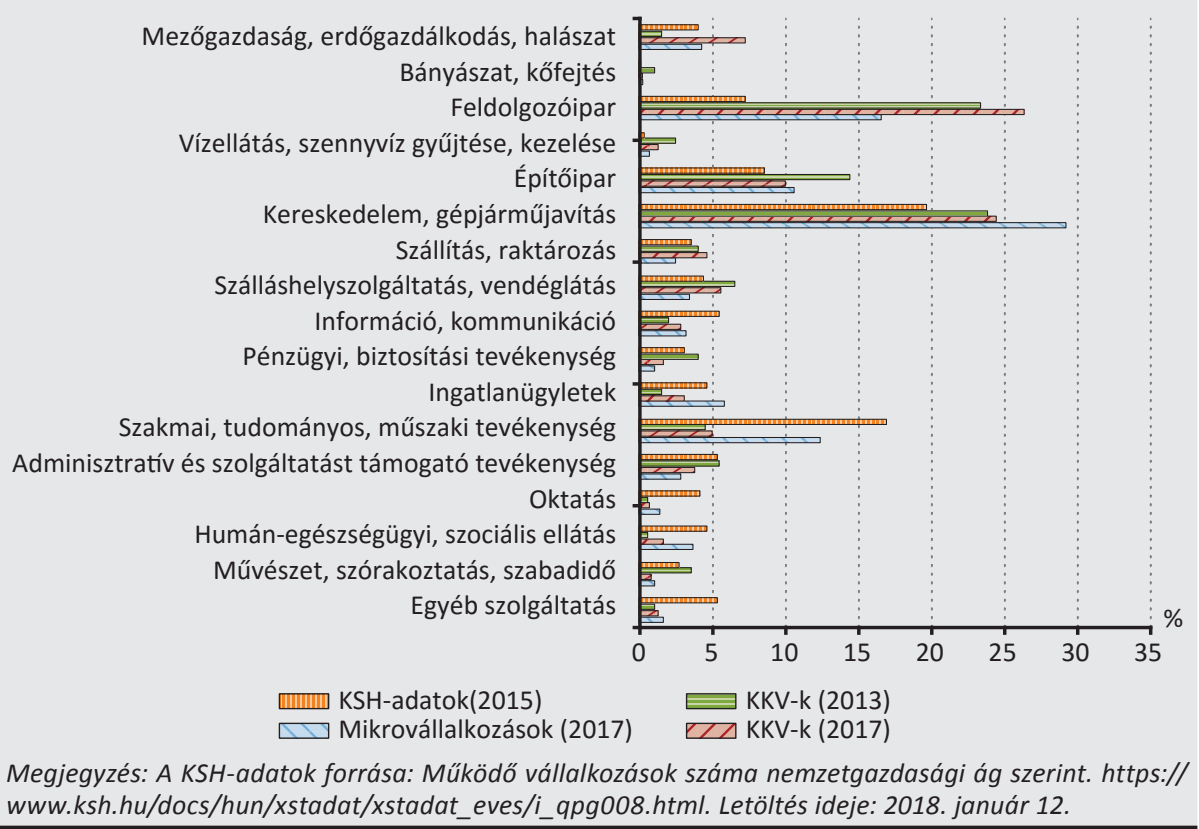

A kvalitatív adatfelvétel során 2017 áprilisában tíz, félig strukturált, témaorientált interjúra került sor, az interjúalanyok minden esetben hazai kis-, illetve középvállalkozások döntéshozói voltak. A válaszadók kiválasztása úgy történt, hogy az ország különböző területein működő, különféle tevékenységgel foglalkozó cégek vezetése során szerzett tapasztalataikat oszthassák meg velünk. Az interjúk szerkezete részben követte a kvantitatív kérdőívek felépítését. A vállalat tevékenységének és az interjúalany abban betöltött szerepének tisztázását követően a beszállítói, majd a vevői kapcsolatok általános bemutatása következett. Ezt követően a fizetési tranzakciók és a készpénzhasználat, valamint a fizetési gyakorlatok és az azokkal kapcsolatos tapasztalatok témaköreinek részletes átbeszélése következett. A kvalitatív kutatási fordulót elsősorban a kérdőív tesztelése, pontosítása érdekében végeztük, illetve abból a célból, hogy kezdeti képet kapjunk az érintett vállalkozások közötti fizetési gyakorlat jellemzőiről. Összegezve az interjúk eredményeit, következtetéseit azt mondhatjuk, hogy az interjúalanyok által elmondottak szinte minden kérdéskörben alátámasztották a kvantitatív felmérés eredményeit. Így a kutatás eredményeinek bemutatása során kizárólag a kérdőíves felmérés adatait elemezzük. 


\section{Kutatási eredmények}

Ebben a fejezetben részletesen bemutatjuk a 2017-es kvantitatív felmérés eredményeit, és ahol módszertanilag lehetséges, összevetjük a 2013-as kutatás eredményeivel. A további összehasonlító elemzést megnehezíti, hogy a készpénzhasználattal, fizetési szokásokkal kapcsolatos cikkek tipikusan a lakosság vizsgálatára szorítkoznak (például Ilyés - Varga 2015, Esselink - Hernández 2017), a KKV-szektorral foglalkozó szakirodalom pedig túlnyomórészt a banki hitelkörnyezettel és a vállalkozások növekedési lehetőségeivel foglalkozik (például Banai et al 2016, Bethlendi - Végh 2014). Nemzetközi viszonylatban az általunk hozzáférhető egyetlen, miénkhez hasonló felmérést a brit adóhivatal ${ }^{1}$ megrendelésére az Ipsos MORI kutatóintézet végezte (Tu-Salmon 2016), melynek releváns eredményeit a 3.1. alfejezetben ismertetjük. Az általuk készített tanulmány a 20 főnél kevesebb alkalmazottal rendelkező vállalkozásokat vizsgálja, ami a magyar fogalom szerinti mikrovállalkozásokat, valamint a kisvállalkozások egy részét foglalja magában. A fizetési fegyelemről szóló 3.4. alfejezetben hivatkozunk továbbá az Intrum Justitia nemzetközi követeléskezelő European Payment Report 2017 címmel publikált tanulmányának adataira.

\subsection{Fizetési szokások, alkalmazott fizetési módok, készpénzhasználat}

A 2017-es felmérés eredménye azt mutatja, hogy a hazai KKV-k és mikrovállalkozások körében a beszállitói és vevői kapcsolatokban vizsgált fizetési módok (készpénzes fizetések, átutalás, bankkártyás fizetések, egyéb) közül egyértelműen a legelterjedtebb fizetési mód az átutalás, ezt követi a készpénzes fizetés, míg a kártyás fizetések e kettőhöz képest sokkal kevésbé használatosak, az egyéb fizetési módok pedig szinte eltúntek a KKV-k és a mikrovállalkozások beszállítói és a vevői kapcsolataiból (2. és 3. ábra). Megjegyezzük, hogy az alkalmazott fizetési módokra vonatkozó kérdés nem egymást kizáró válaszlehetőségeket kínált, mivel egy vállalkozás többféle fizetési módot is alkalmazhat, bár az egyes változatok használati gyakorisága nyilvánvalóan eltérhet egymástól.

\footnotetext{
${ }^{1}$ Her Majesty's Revenue and Customs
} 


\section{2. ábra \\ Az egyes fizetési módokat alkalmazók aránya a beszállítói kapcsolatoknál}

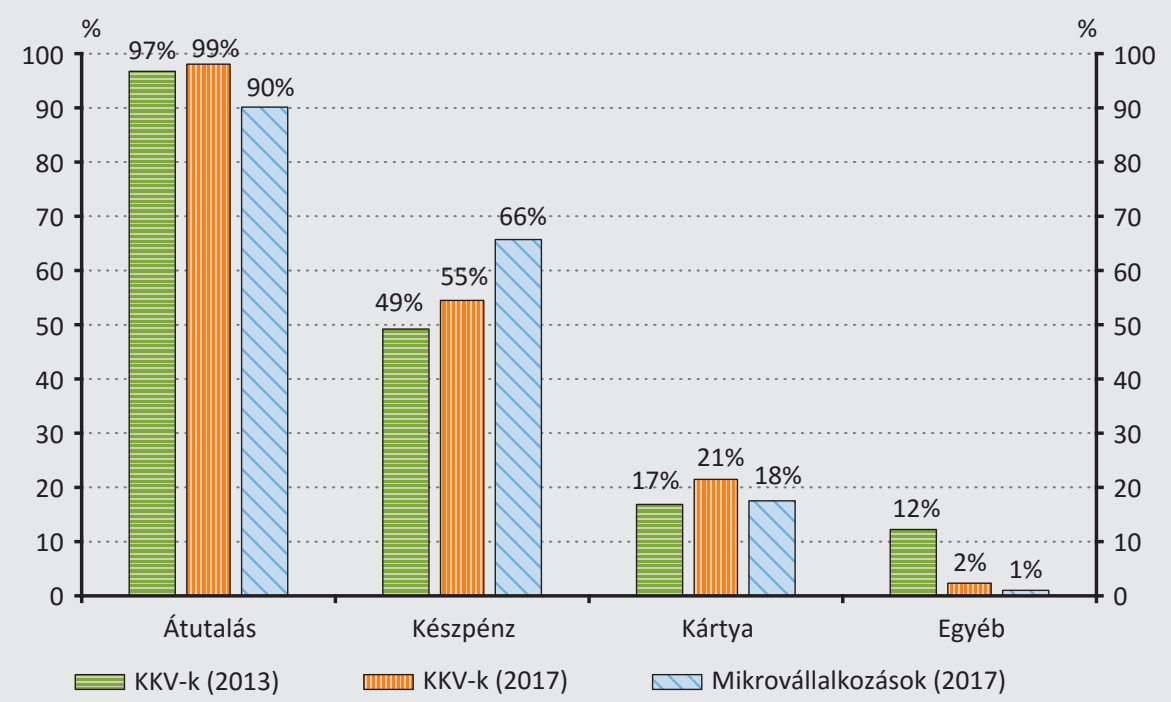

\section{3. ábra}

Az egyes fizetési módokat alkalmazók aránya a vevői kapcsolatoknál

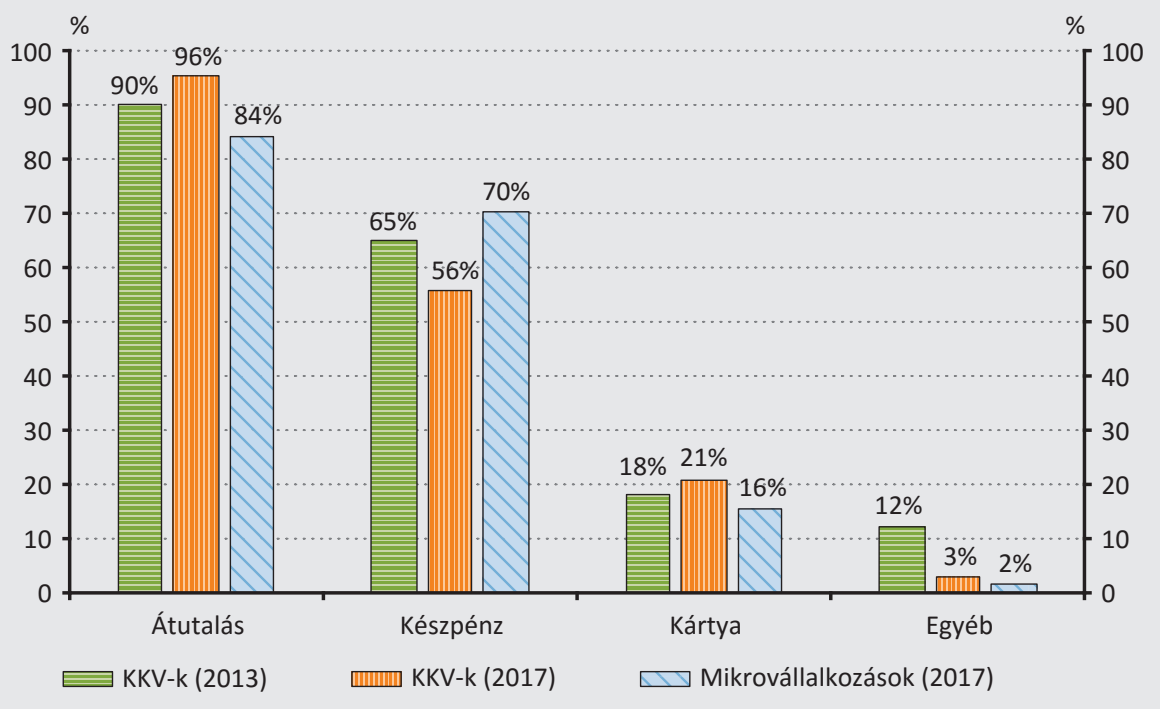


Az átutalásról elmondható, hogy elterjedtsége a KKV-k körében 2013 óta tovább nőtt, gyakorlatilag teljes körünek tekinthetö, azaz majdnem mindegyik indít és fogad átutalással fizetéseket. A mikrovállalkozásoknak a 90 százaléka használja ezt a fizetési módot saját fizetési kötelezettségei teljesitésére, illetve 84 százalékuk fogad is ilyen módon bejövő fizetéseket.

A készpénzes fizetést tekintve mind a KKV-k, mind a mikrovállalkozások esetében többségben vannak azok, amelyek használják ezt a fizetési módot, azokhoz képest, amelyek készpénzmentesen múködnek, akár a beszerzési, akár az értékesítési oldalt nézzük. A KKV-knál a beszállitói kapcsolatokban készpénzt használók aránya némileg még növekedett is 2013-hoz képest (49-ről 55 százalékra), a vevői kapcsolataikban készpénzt használók arányában viszont csökkenés figyelhető meg (65-ről 56 százalékra). Ezek a változások azért is figyelemre méltók, mert - ahogy azt a későbbiekben látni fogjuk - a készpénzhasználat motivációi között előkelő helyen szerepel a vevői preferencia, azaz a vállalkozások a saját készpénzhasználatukat jelentős mértékben azzal indokolják, hogy a bevételeik egy része készpénzben keletkezik. A készpénzt használó vállalkozások aránya a vevői és a beszállitói oldalon közel azonos (az ellenkező irányú változások eredményeként jelenleg 56, illetve 55 százalék), ami viszont arra utal, hogy azok a vállalkozások, amelyeknek a vevői oldalon keletkeznek készpénzes bevételeik, inkább a beszállítóik kifizetésére használják fel a készpénzt, minthogy befizessék a bankszámlájukra.

Az üzleti kártyás ${ }^{2}$ fizetést alkalmazó vállalkozások aránya továbbra is rendkívül alacsonynak mondható, bár enyhén emelkedett 2013-hoz képest (a növekedés kicsi ugyan, de 95 százalékos konfidenciaszint mellett szignifikánsnak mondható). A KKV-k körében a kártyás fizetést alkalmazók aránya mindössze 21 százalék, nem figyelhető meg érdemi növekedés 2013-hoz képest, míg a mikrovállalkozások még ennél is kisebb arányban használják ezt a fizetési módot (18 százalék). A vevői oldalon hasonlóan alacsony arány látható: a hazai KKV-knak mindössze 21 százaléka, a mikrovállalkozásoknak pedig csak 16 százaléka fogad el kártyás fizetést. Adataink elmaradnak az MNB (2018) által publikált Fizetési rendszer jelentésben szereplő 30 százalékos elfogadási aránytól, ennek fő oka, hogy utóbbi érték a 2016-os OPG-adatbázison ${ }^{3}$ alapul, mely túlnyomórészt kiskereskedelmi üzleteket, kisebb részben pedig vendéglátó- és szálláshelyeket tartalmaz. A kártyaelfogadó vállalkozások szektoronkénti megoszlását a jelen kutatás keretében nem vizsgáltuk, de az az alapadatokból is megállapítható, hogy a kártyaelfogadó vállalkozások aránya - mind a KKV-k, mind a mikrovállalkozások esetében - elmarad azoknak a vállalkozásoknak az együttes arányától, amelyek tevékenységük alapján azokba a szektorokba tartoznak, ahol egyébként leginkább jellemző a kártyaelfogadás (kereskedelem, gépjármújavítás,

\footnotetext{
${ }^{2}$ Nem különböztettük meg a felmérésben a hitel-, illetve betéti kártya alkalmazását, csak az üzleti kártyahasználatra mint fizetési módra voltunk kíváncsiak.

${ }^{3}$ Online pénztárgép adatbázis
} 
vendéglátás, szálláshelyszolgáltatás) ${ }^{4}$. Ez pedig arra utal, hogy még ezekben a szektorokban is rejlik potenciál a kártyaelfogadás bővítésére.

A kutatási eredmények alapján az egyéb fizetési módoknál erőteljes visszaesés tapasztalható azzal együtt, hogy jelentősen változott a megkérdezettek által megnevezett egyéb fizetési módok köre is. Míg 2013-ban többen is megjelölték az akkreditívet és az inkasszót mint általuk használt fizetési módot, addig 2017-ben a megkérdezettek jellemzően az utalványokat, az utánvételt, illetve a „postai csekket" nevezték meg általuk alkalmazott egyéb fizetési módként ${ }^{5}$.

Eredményeinket összehasonlítva a korábban említett, Nagy-Britanniára vonatkozó felméréssel (Tu -Salmon 2016), megállapíthatjuk, hogy a magyar vállalkozások leginkább a kártyahasználat terén maradnak el brit társaiktól, mivel a szigetországban a vizsgált cégek 42 százaléka lehetővé teszi vevői számára a kártyás fizetést (szemben az itthoni mikrovállalkozásokra vonatkozó 16 százalékkal), az átutalás lehetőségét viszont csak 67 százalék biztosítja (míg Magyarországon a mikrovállalkozások esetén ugyanez az arány 84 százalék).

Az egyes fizetési módok elterjedtsége nemcsak abból a szempontból vizsgálható, hogy a vállalkozások mekkora hányada alkalmazza őket, hanem abból a szempontból is, hogy az adott fizetési módot alkalmazó vállalkozások a fizetési kötelezettségeik teljesítéséhez milyen arányban használják azt. Az átutalás dominanciája ebből a szempontból is egyértelmüen megállapitható. Ahogy az előzőekben láthattuk, a KKV-k csaknem mindegyike (99 százaléka) használja a beszállítói kapcsolataiban az átutalást, de a felmérés eredménye azt is megmutatta, hogy az átutalást használók jelentős többsége (83 százaléka) a fizetési kötelezettségeinek a 76-100 százalék között részét ezzel a fizetési móddal is teljesíti. A vevői kapcsolatok oldaláról nézve az látható, hogy a KKV-k 96 százaléka használja az átutalást bejövő fizetések fogadására, és az átutalást használók 76 százalékánál a bejövő tranzakciók legalább háromnegyed része ilyen módon is teljesül. A mikrovállalkozásokról is elmondható, hogy az átutalás az általuk legáltalánosabban alkalmazott fizetési mód: 90 százalékuk használja, és a használók 56 százaléka a fizetési kötelezettségeinek legalább a háromnegyedét ilyen módon is teljesíti.

Bár a vállalkozások többsége használ készpénzt a beszállítói és a vevői kapcsolataiban egyaránt, a készpénzzel lebonyolitott fizetési müveletek a tranzakcióknak csak kisebb hányadát érintik. A készpénzt használó KKV-k többsége (73 százalék) csak a fizetési kötelezettségeinek legfeljebb 25 százalékát teljesíti készpénzfizetéssel, és a vevői oldalon is többségben vannak azok ( 62 százalék), amelyeknél csak a tranzakciók legfeljebb egy negyedében történik készpénzes fizetés. $A$ döntően (a tranzakciók legalább háromnegyed részében) csak készpénzt használók aránya a KKV-knál mindössze 4 százalék a beszállitói és 11 százalék a vevői oldalon (4. és 5. ábra).

${ }^{4}$ A kutatásban részt vevő vállalkozások szektoronkénti megoszlását a 2. fejezet mutatja be.

${ }^{5}$ A válaszadók által „postai csekknek” nevezett fizetési mód - akár a készpénzátutalási megbízásra, akár a postautalványra gondoltak - gyakorlatilag készpénzes fizetésnek tekinthető éppúgy, mint az utánvétel. 


\section{4. ábra}

A készpénzfizetés alkalmazása a KKV-k beszállítói kapcsolataiban

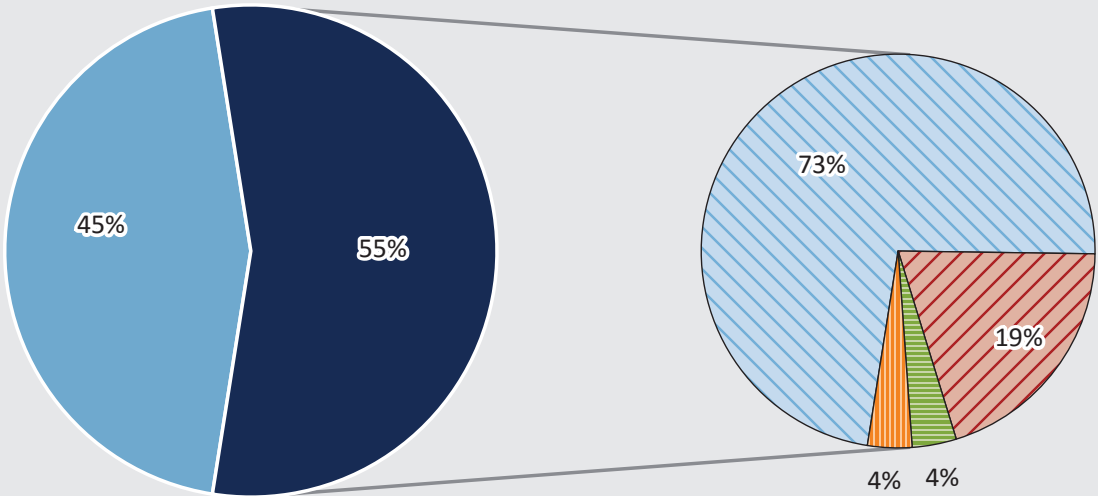

Használ készpénzt Nem használ készpénzt $\square$ A kifizetések 0-25\%-át teljesíti készpénzzel $\backslash \lambda$ A kifizetések 26-50\%-át teljesíti készpénzzel A kifizetések 51-75\%-át teljesíti készpénzzel mum A kifizetések 76-100\%-át teljesíti készpénzzel

\section{5. ábra}

A készpénzfizetés alkalmazása a KKV-k vevői kapcsolataiban

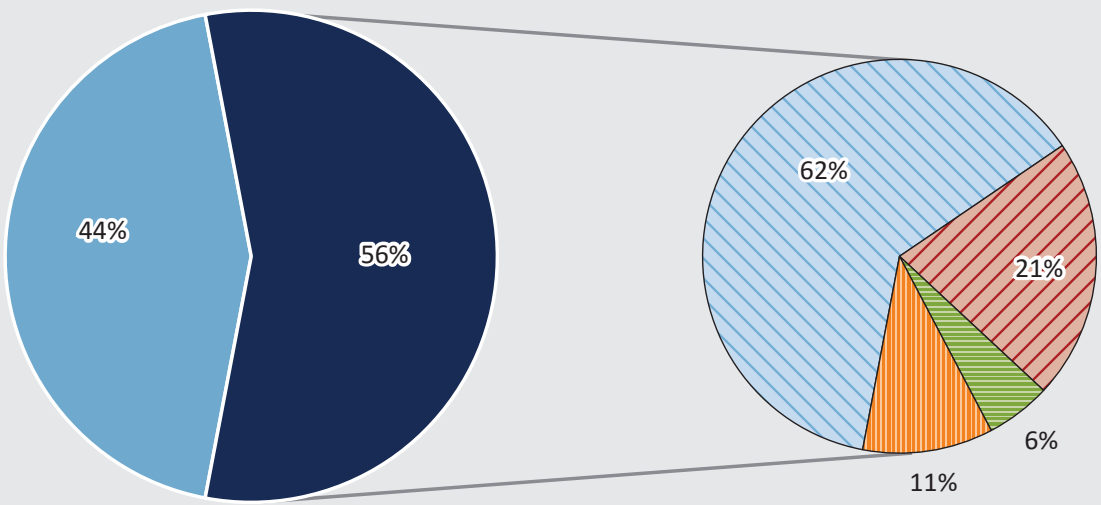

Használ készpénzt Nem használ készpénzt $\square$ A bejövő fizetések 0-25\%-a teljesül készpénzzel Z A bejövő fizetések 26-50\%-a teljesül készpénzzel Е A bejövő fizetések 51-75\%-a teljesül készpénzzel 血而 A bejövő fizetések 76-100\%-a teljesül készpénzzel 
A mikrovállalkozások körében a készpénzfizetés elterjedtebb, mint a KKV-knál, nemcsak a készpénzt használók arányát (beszállítói oldalon 66, vevői oldalon 70 százalék), hanem a készpénzes tranzakciókat előnyben részesítők arányát tekintve is. A mikrovállalkozások közel egy ötöde a fizetési kötelezettségeinek legalább háromnegyedét készpénzben teljesíti, és 28 százalékuknál a bejövő fizetéseknek is legalább háromnegyed része készpénzben érkezik (6. és 7. ábra).

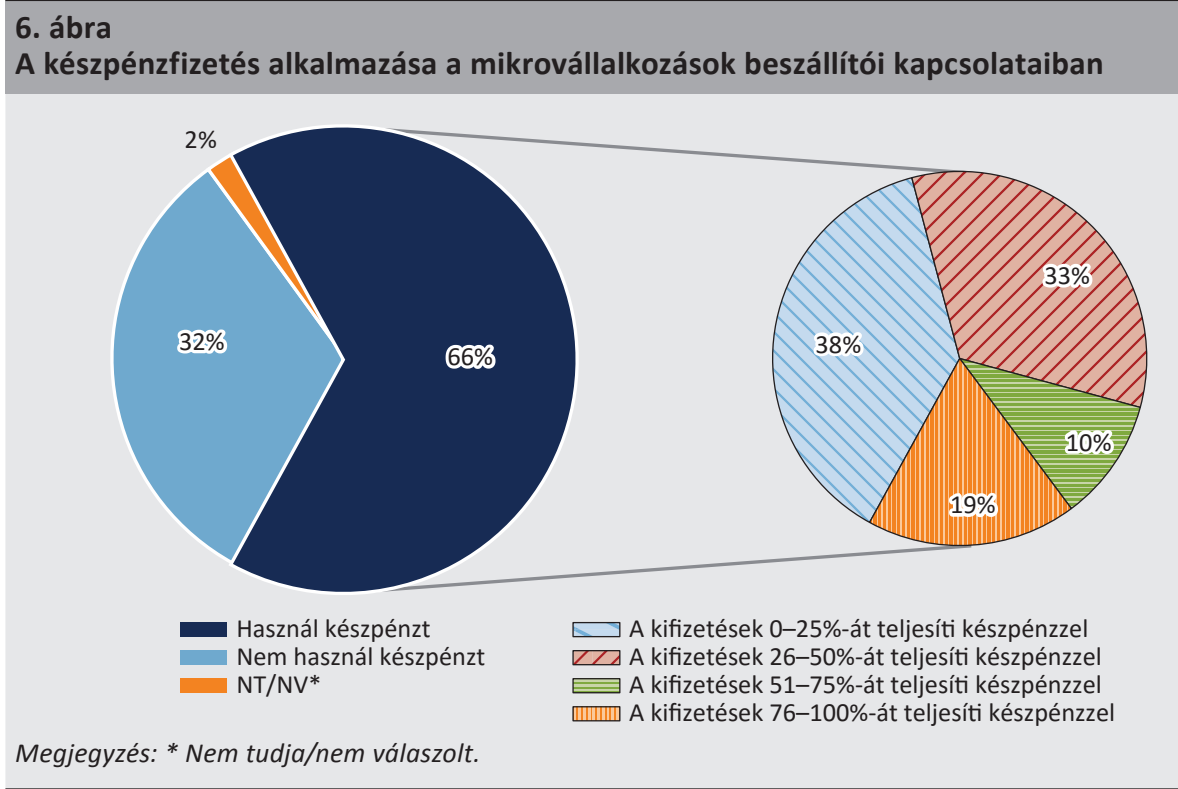

\section{7. ábra}

A készpénzfizetés alkalmazása a mikrovállalkozások vevői kapcsolataiban

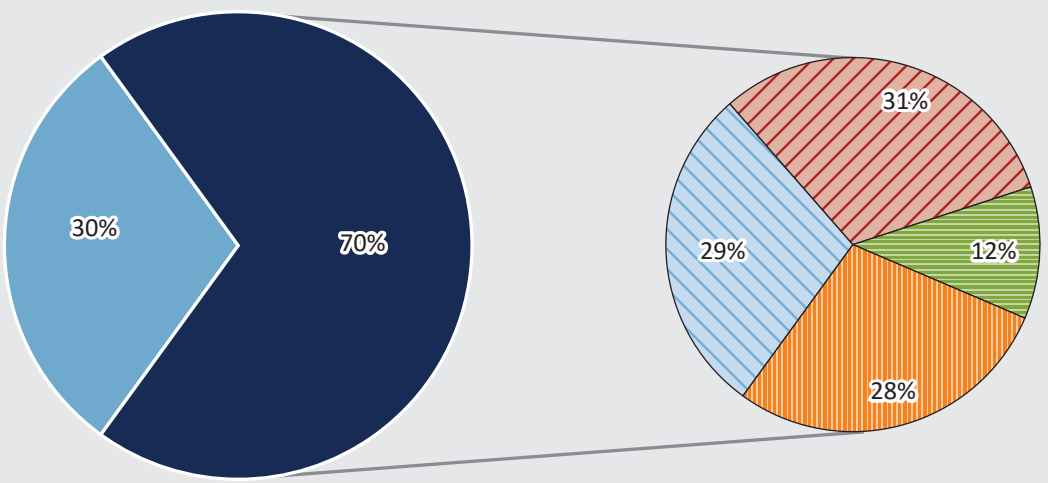

Használ készpénzt Nem használ készpénzt $\square$ A bejövő fizetések 0-25\%-a teljesül készpénzzel $\square$ A bejövő fizetések 26-50\%-a teljesül készpénzzel —A bejövő fizetések 51-75\%-a teljesül készpénzzel 血盂 A bejövő fizetések 76-100\%-a teljesül készpénzzel 
Brit társaikkal összehasonlítva a magyar mikrovállalkozások jellemzően nem használnak nagyobb mértékben készpénzt vevőkapcsolataikban. Míg itthon mindössze 9,4 százalékuk intézi minden tranzakcióját készpénzes úton, Nagy-Britanniában 13 százalékuk nem vesz igénybe semmilyen elektronikus fizetési módot, jellemzően azok magas költségei miatt. A beszállítói kapcsolatokat vizsgálva vegyes következtetéseket vonhatunk le. A magyar mikrovállalkozások 7 százaléka használ kizárólag készpénzt ebben a relációban, ugyanez a szám Nagy-Britanniában pedig 19 százalék, ugyanakkor a szigetországban 54 százalék teljes mértékben elektronikus úton fizet beszállítóinak, míg itthon ez az arány csak 32 százalék.

A KKV-k körében a három vizsgált fizetési mód közül a megkérdezettek a bankkártyát használják legkevésbé, mindössze 21 százalékuk alkalmazza, és ők is jellemzően ritkán veszik igénybe ezt a módszert. Döntő többségük (89 százalékuk) tranzakcióinak legfeljebb 25 százalékában használja fizetésre a bankkártyáját, illetve a bankkártyát elfogadók jelentős részénél (73 százalékánál) csak a tranzakciók legfeljebb negyedében történik kártyás fizetés. A kártyás fizetések - a KKV-khoz hasonlóan - a mikrovállalkozásoknál is csak kiegészítő szerepet töltenek be.

Az eddig bemutatott eredmények alapján az a következtetés vonható le, hogy a vállalkozások közötti üzleti kapcsolatokban a készpénzhasználat még mindig erőteljesen jelen van - a mikrovállalkozásoknál inkább, a KKV-knál valamivel kevésbé -, mértéke pedig 2013-hoz képest dominánsan nem változott. Bár a készpénzes fizetés gyakorisága az átutaláshoz képest másodrangúnak tekinthető, szerepe nem elhanyagolható. Annak ellenére, hogy az átutalások tovább erősítették dominanciájukat az elmúlt négy év során, a KKV-knál nem tapasztalható elmozdulás a készpénzmentes müködés felé, a mikrovállalkozások esetében pedig különösen erősnek tekinthető a készpénz jelenléte a fizetésekben.

Mivel kutatásunk fókuszában alapvetően a vállalkozások készpénzhasználata állt, külön megvizsgáltuk a készpénzes fizetések tranzakciónkénti átlagos értékét is a beszállítói kapcsolatokban (kimenő fizetések) és a vevői kapcsolatokban (bejövő fizetések) egyaránt (8. és 9. ábra). Ahogy az ábrákon látható, továbbra is az alacsony értékủ (50 ezer forint alatti) tranzakciók vannak többségben mindkét pénzmozgási irányban. Érdekes módon viszont az is megfigyelhető, hogy 2013-hoz viszonyítva a készpénzes tranzakciók értéke eltolódott a nagyobb összegek felé: szignifikáns növekedés figyelhető meg a 100 ezer és 500 ezer forint közötti kategóriában mindkét irányban, míg az 500 ezer forintot meghaladó kategóriában a beszállítók felé indított fizetéseknél. A kutatás részét képező mélyinterjúk alapján valószínűsíthető, hogy a jelenség fő oka a 2013-ban bevezetett tranzakciós illeték, melyet a pénzintézetek jellemzően áthárítanak ügyfeleikre. A megfigyeltek emellett alátámasztják azt a korábban már említett feltételezésünket is, hogy a hazai vállalkozások a készpénzben keletkező bevételeiket inkább a beszállítóik felé történő fizetésre használják (még a nagyobb összegú beszerzések esetén is), minthogy befizessék azt a fizetési számlájukra. 


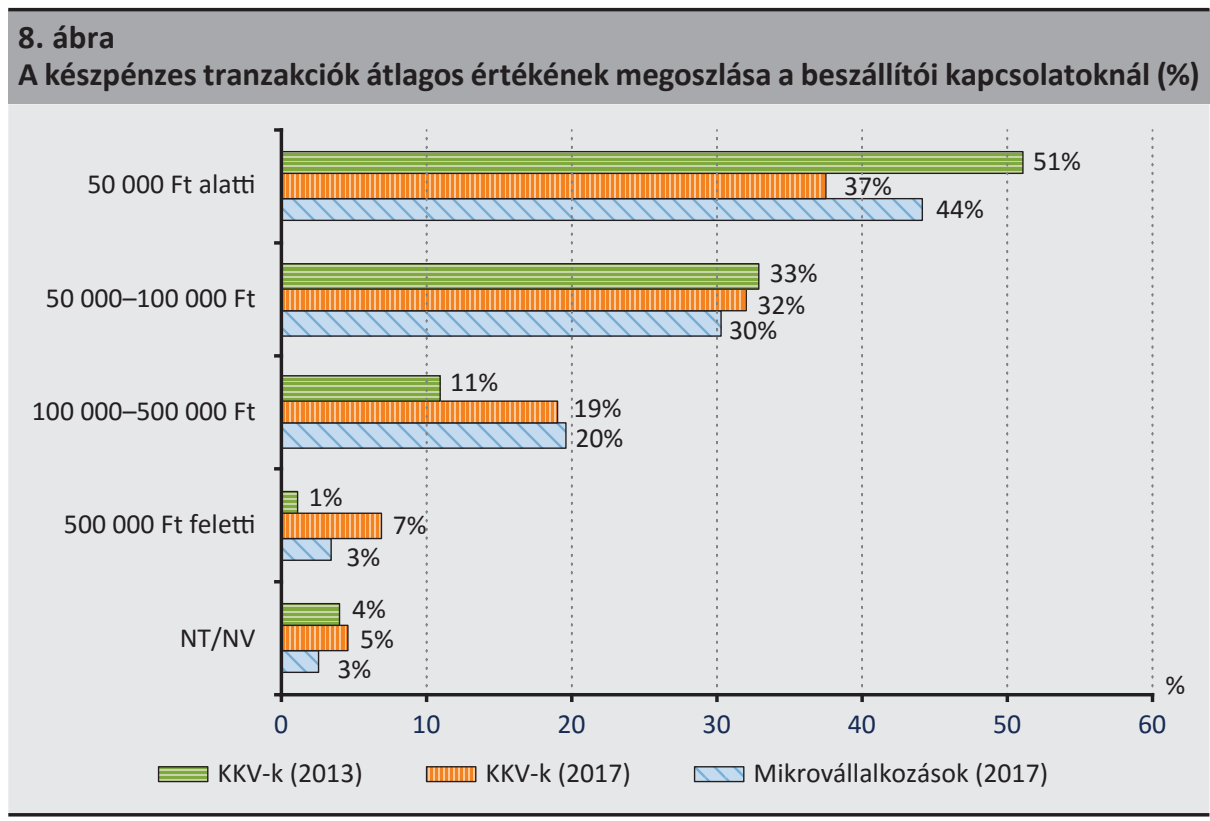

\section{9. ábra \\ A készpénzes tranzakciók átlagos értékének megoszlása a vevői kapcsolatoknál (\%)}

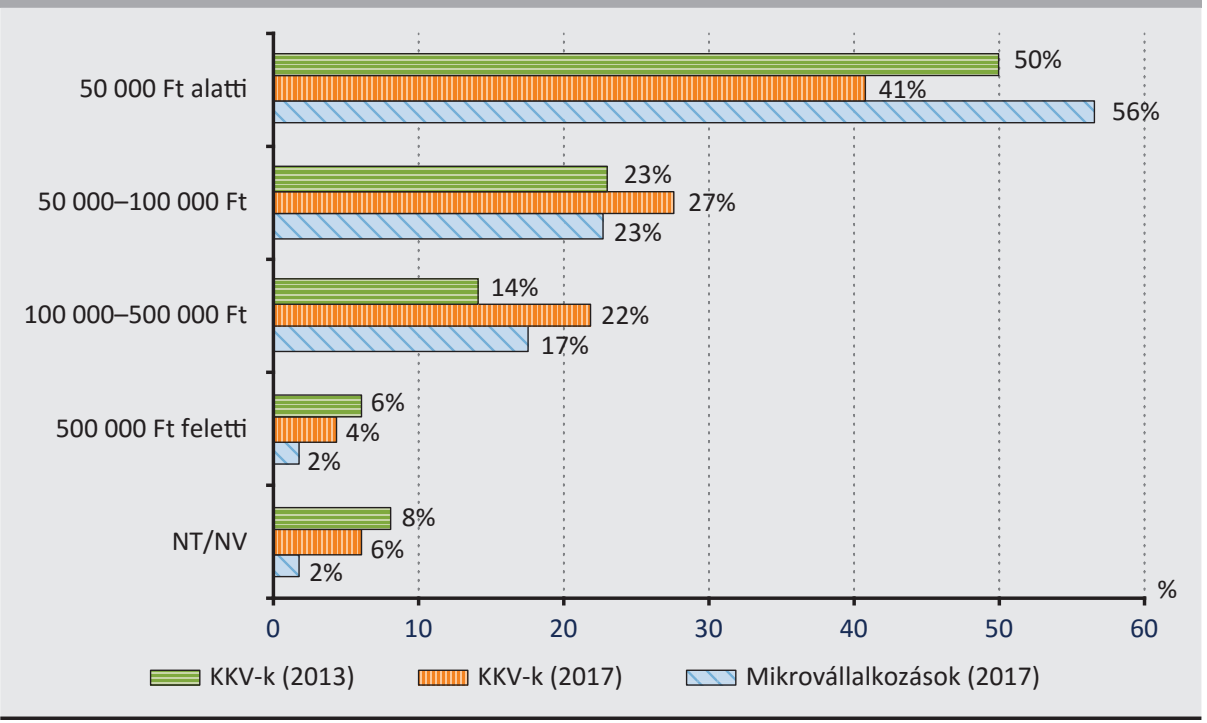


A 2017-es felmérés során a beszállítói és a vevői kapcsolatokban alkalmazott fizetési módok mellett rákérdeztünk arra is, hogy a vállalkozások jellemzően milyen fizetési módokat használnak a közüzemi számláik fizetésére (10. és 11. ábra). A válaszadóknak azt kellett megmondaniuk, hogy a megnevezett fizetési módokat (készpénz, készpénzátutalási megbízás ${ }^{6}$, átutalás, csoportos beszedés) használják-e a közüzemi számláik fizetése során, vagy nem. Mivel a vállalkozások az egyes közüzemi számlákat különböző módokon is fizethetik, egy válaszadó értelemszerűen több fizetési módot is megjelölhetett. A grafikonokon a készpénz a közüzemi szolgáltató ügyfélszolgálatánál teljesített, közvetlen készpénzbefizetést, a készpénzátutalási megbízás a „sárga csekkel” (például a postai fiókokban) teljesített befizetést használó vállalkozások arányát mutatja.

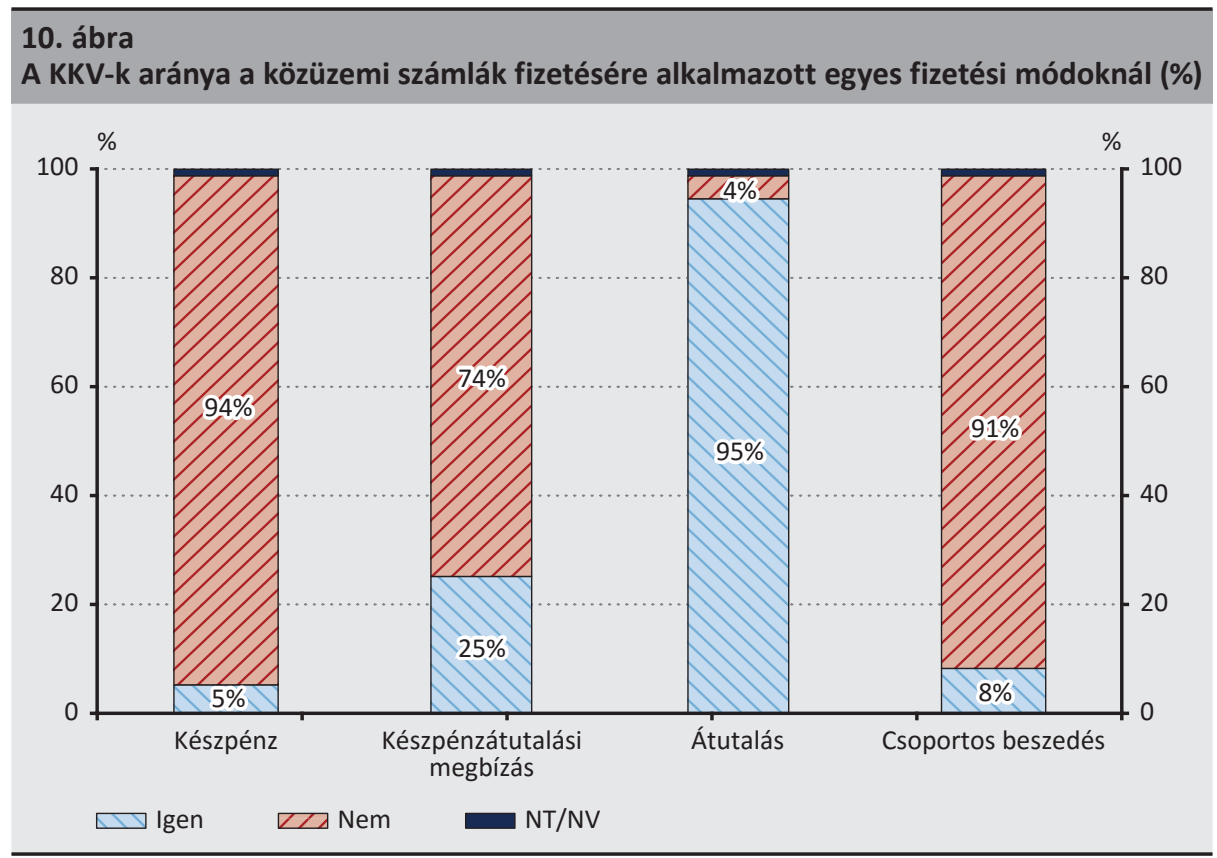

${ }^{6}$ ún. „sárga csekk” 


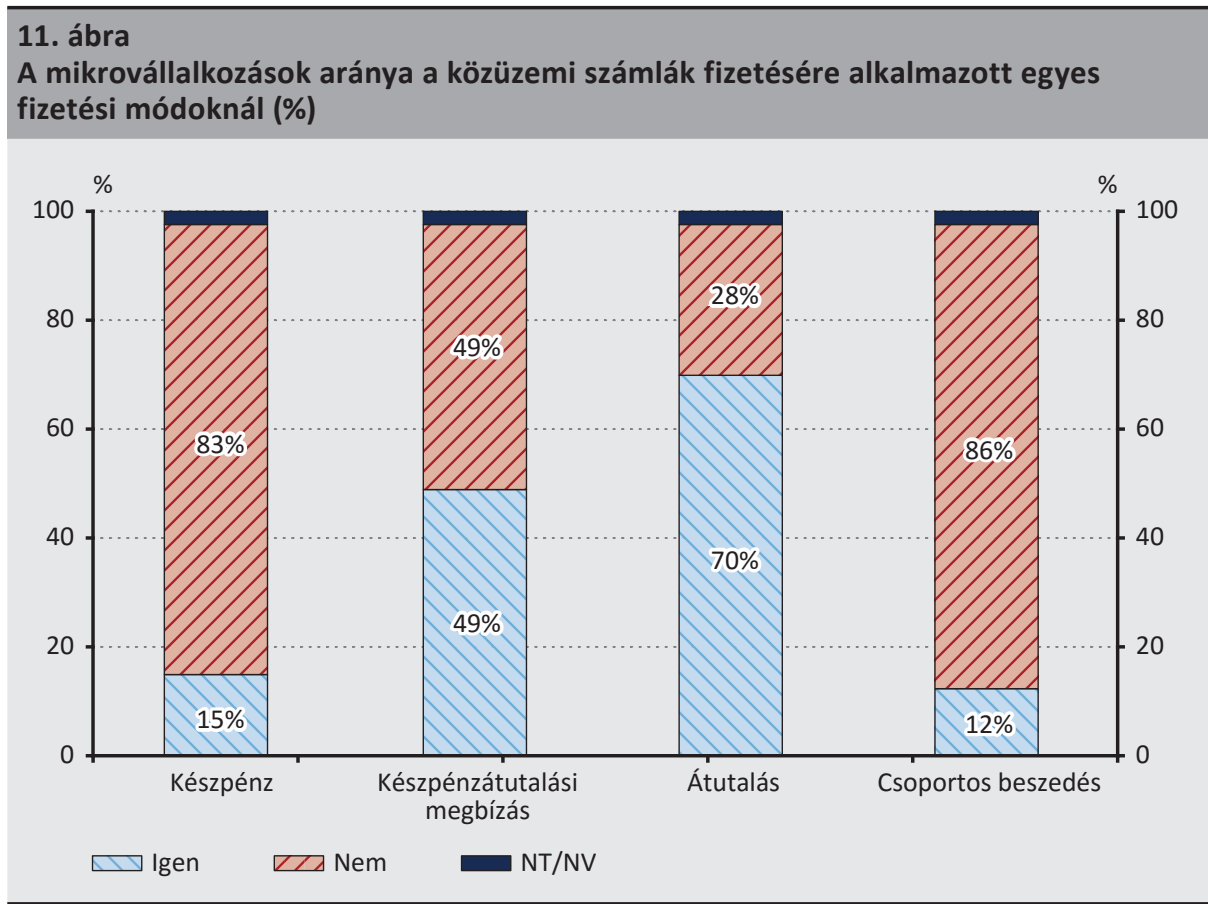

A legtöbben a közüzemi számláik kiegyenlítésére is az átutalást használják, de a készpénzes fizetése $k^{7}$ is meglehetősen népszerüek. A készpénzátutalási megbízást a KKV-k negyede, míg a mikrovállalkozások fele alkalmazza, de a közvetlen készpénzes fizetést is használja a KKV-k 5, a mikrovállalkozások 15 százaléka. Ebben a kérdéskörben a leginkább szembetűnő eredmény, hogy a csoportos beszedést, amely éppen az olyan jellegú fizetési kötelezettségekre szolgáló fizetési mód, mint a közüzemi díjak teljesítése, rendkívül kevés hazai vállalkozás használja, a KKV-knak mindössze 8, a mikrovállalkozásoknak 12 százaléka él ezzel a fizetési lehetőséggel.

A vállalkozások számára a beszállítók és a közüzemi díjak mellett a munkabérek jelentenek rendszeres fizetési kötelezettséget. A kutatás során ezért rákérdeztünk arra is, hogy a munkabéreket milyen arányban fizetik készpénzzel, és milyen arányban átutalással (12. ábra). A kérdés kizárólag a pénzben rendszeresen fizetett munkabérre vonatkozott, az egyéb juttatások (például étkezési utalvány) nem szerepeltek a felmérésben.

${ }^{7}$ Bár a készpénzátutalási megbízás esetében már van lehetőség kártyás fizetésre is, a vállalkozások körében a beszállítói kapcsolatoknál tapasztalt alacsony kártyahasználat miatt jellemzően ezt is inkább készpénzes fizetésnek tekinthetjük. 
A válaszok alapján a vállalkozásokat 5 csoportba soroltuk aszerint, hogy a munkabérek kifizetését milyen arányban teljesítik készpénzzel. ${ }^{8}$ Mind $a K K V-k$, mind a mikrovállalkozások esetén a bérfizetés legjellemzőbb módja az átutalás, a KKV-k közel 60 százaléka, míg a mikrovállalkozások több mint 40 százaléka kizárólag ezen a módon fizeti ki alkalmazottait. Azonban míg a KKV-k esetén az egyre nagyobb arányú készpénzes bérfizetéshez tartozó csoportokba egyre kevesebb válaszadó tartozik, és csupán 5 százalék azok aránya, amelyek erre a célra egyáltalán nem használnak átutalást, addig a megkérdezett mikrovállalkozások számottevő hányada, 36 százaléka teljes mértékben készpénzzel fizeti ki a munkabéreket. Érdemes még kiemelni, hogy felmérésünk szerint a mikrovállalatok nagyjából 50 százaléka alkalmazottai bérének legalább felét készpénzben fizeti ki, míg ugyanezen arány a KKV-k körében jóval kisebb, 23 százalékos. Előző feltételezésünket - különösen a mikrovállalkozások esetén - úgy egészíthetjük tehát ki, hogy a vállalatok a hozzájuk a vevők irányából beáramló készpénzt főként a beszállítói kötelezettségek teljesítésére fordítják, de nem elhanyagolható mértékben ezzel rendezik az alkalmazottak fizetését is. A munkavállalók számára készpénzben történő fizetés egyértelműen tranzakciós készpénzforgalmat generáló tényező, hiszen azok a munkavállalók, akik készpénzben kapják a jövedelmüket, nyilván a háztartási kiadásaikat is készpénzben rendezik majd.

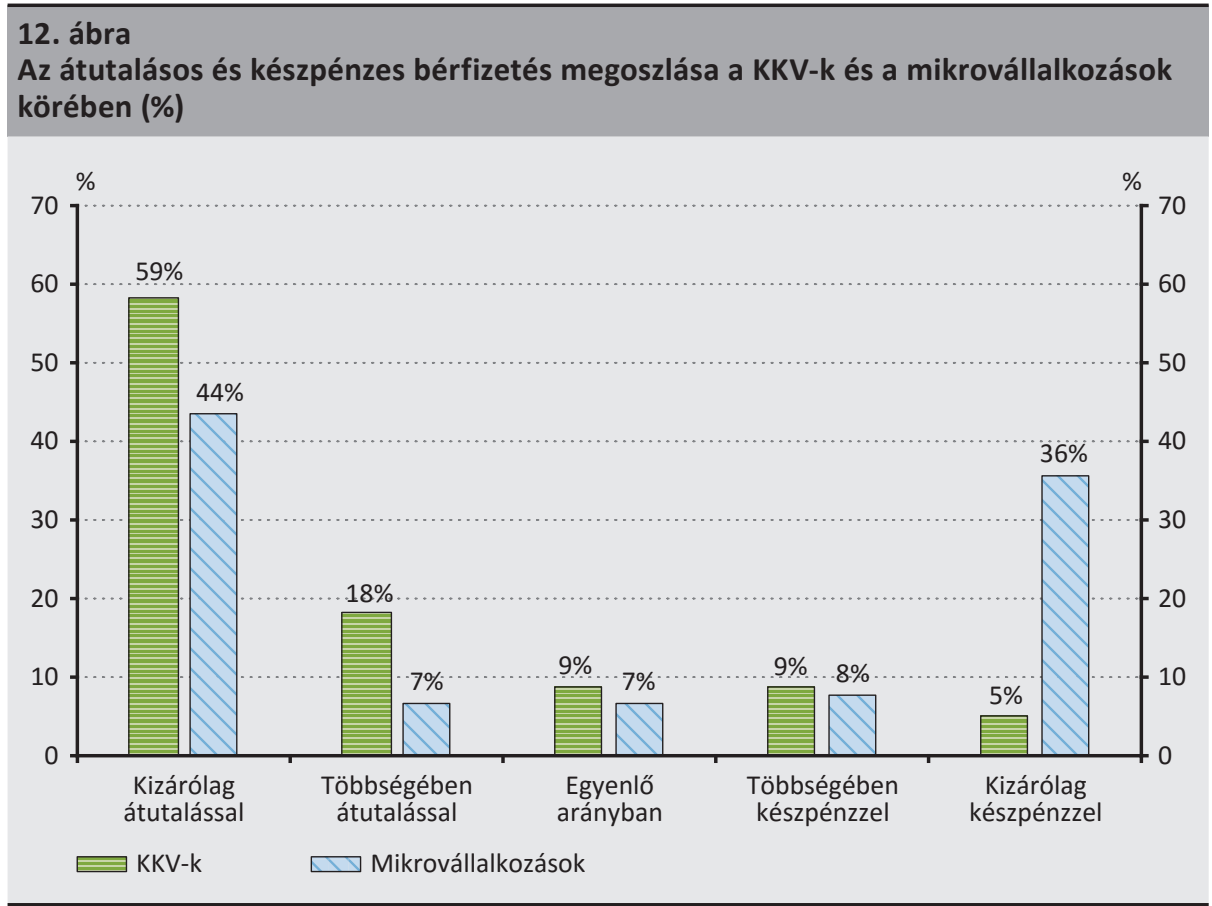

${ }^{8}$ 0\%: „Kizárólag átutalással”, 1-49\%: „Többségében átutalással”, 50\%: „Egyenlő arányban”, 51-99\%: „Többségében készpénzzel”, illetve 100\%: Kizárólag készpénzzel. 
Nemzetközi összehasonlításban is kijelenthető, hogy a hazai mikrovállalkozások nagy arányban használnak készpénzt a munkabérek kifizetésére, hiszen a hivatkozott brit adatok szerint ott a vállalkozások 64 százaléka teljes mértékben átutalással rendezi bérköltségeit, míg a kizárólagos készpénzhasználat csak 23 százalékuk esetén fordul elő.

\subsection{Szabályozói intézkedések hatása a vállalkozások fizetési szokásaira}

A 2013-as felmérés kérdései között szerepelt az is, hogy a fizetési forgalmat befolyásoló egyes adminisztratív, szabályozói intézkedések bevezetése hatással volt-e a felmérésben részt vevő KKV-k készpénzforgalmára, és ha igen, milyen irányban. Az akkori felmérés eredménye szerint a vizsgált intézkedések (a napon belüli átutalás, a vállalkozások egymás közötti készpénzfizetéseire bevezetett korlátozás és a tranzakciós illeték) egyike sem okozott szignifikáns változásokat a vállalkozások fizetési gyakorlatában, illetve az összesített hatásukra vonatkozó kérdésre adott válaszok is azt mutatták, hogy az intézkedések nem voltak érdemi befolyással a KKV-k készpénzforgalmának mértékére sem a kimenő, sem a bejövő fizetési irányban. Ezen megállapításokat llyés et al. (2014) vállalati, valamint lakossági pénzforgalmi jellemzőket vizsgáló kutatása is alátámasztotta. Tekintettel azonban arra, hogy a 2013-as adatfelvételre az intézkedések bevezetését követően nem sokkal került sor, illetve a szabályozás a tranzakciós illeték esetében időközben módosult is, a 2017-es kutatásunkban a két intézkedés (a napon belüli átutalás és a tranzakciós illeték) készpénzforgalomra gyakorolt esetleges hatásaira a KKV-knál ismételten rákérdeztünk.

A napon belüli átutalás készpénzhasználatra gyakorolt hatása tekintetében a 2017es felmérés eredménye kettősséget mutat: egyrészről 2013-hoz képest jelentősen csökkent azoknak a vállalkozásoknak az aránya, amelyek úgy vélik, hogy ennek a lehetőségnek saját vállalkozásuk szempontjából érzékelhető hatása van (87 százalékról 56 százalékra); másrészről viszont összességében növekedett azoknak az aránya, amelyek a napon belüli átutalásnak köszönhetően a készpénzes forgalmuk egy részét elektronikus átutalással tudták felváltani (ők a napon belüli átutalás hatását érzékelő válaszadóknak mindössze 11 százalékát tették ki 2013-ban, 2017-ben viszont már 48 százalékát, ami a teljes mintát tekintve a vállalkozások 10 százalékát jelentette 2013-ban, és 27 százalékát 2017-ben). Ezek az eredmények arra utalnak, hogy a vállalkozások egy jelentős része számára a napon belüli teljesítés már természetes velejárója lehet az átutalási fizetési módnak, így ezt külön előnyként már nem érzékelik. Egyértelműen látható ugyanakkor, hogy a vállalkozások készpénzhasználatának visszaszorítására az elektronikus fizetések fejlesztésének közvetlen hatása van, amit alátámasztanak a készpénzhasználat csökkentésének ösztönzőire vonatkozó kérdéseinkre adott válaszok is (Id. 3.6. fejezet).

A tranzakciós illeték esetében az látható, hogy kismértékben megnövekedett azoknak a vállalkozásoknak az aránya, amelyek úgy nyilatkoztak, hogy a tranzakciós illeték nem befolyásolja a vállalkozásuk által alkalmazott fizetési gyakorlatot (2017- 
ben ez az arány 73 százalék, míg 2013-ban 68 százalék volt). Azoknál, amelyeknél változott a fizetési gyakorlat, a legszélesebb körben (70 százalékuknál) alkalmazott eljárás, hogy a partnerek felé indított egyes elektronikus fizetéseket összevonják az illetékfizetés felső korlátjának elérése érdekében. A kimenő, illetve a bejövő fizetéseknél megnövekvő készpénzforgalomról csak a vállalkozások kisebb hányada (15, illetve 16 százalék) számolt be, ami a teljes mintára vetítve a vállalkozásoknak mindössze 4 százalékát jelenti.

\subsection{A készpénzhasználat motivációi}

A vállalkozásoknak kötelező pénzforgalmi bankszámlával rendelkezniük. Ebben a körben tehát - ellentétben a lakossággal - általános a banki kapcsolat megléte, a banki szolgáltatásokhoz való hozzáférés. Vajon mi motiválja a vállalkozásokat, hogy a kutatás során látott arányban fizessék készpénzben a beszállítóikat, illetve vevőiktől készpénzes fizetést fogadjanak el? A kvantitatív felmérés során a megkérdezettek legnagyobb arányban a kis értéknagyságot, valamint a vevői preferenciát jelölték meg a készpénz használatának fő motivációjaként (13. és 14. ábra) ${ }^{9}$.

\section{3. ábra}

\section{A készpénzhasználat okai a KKV-k beszállítói és vevői kapcsolataiban (\%)}

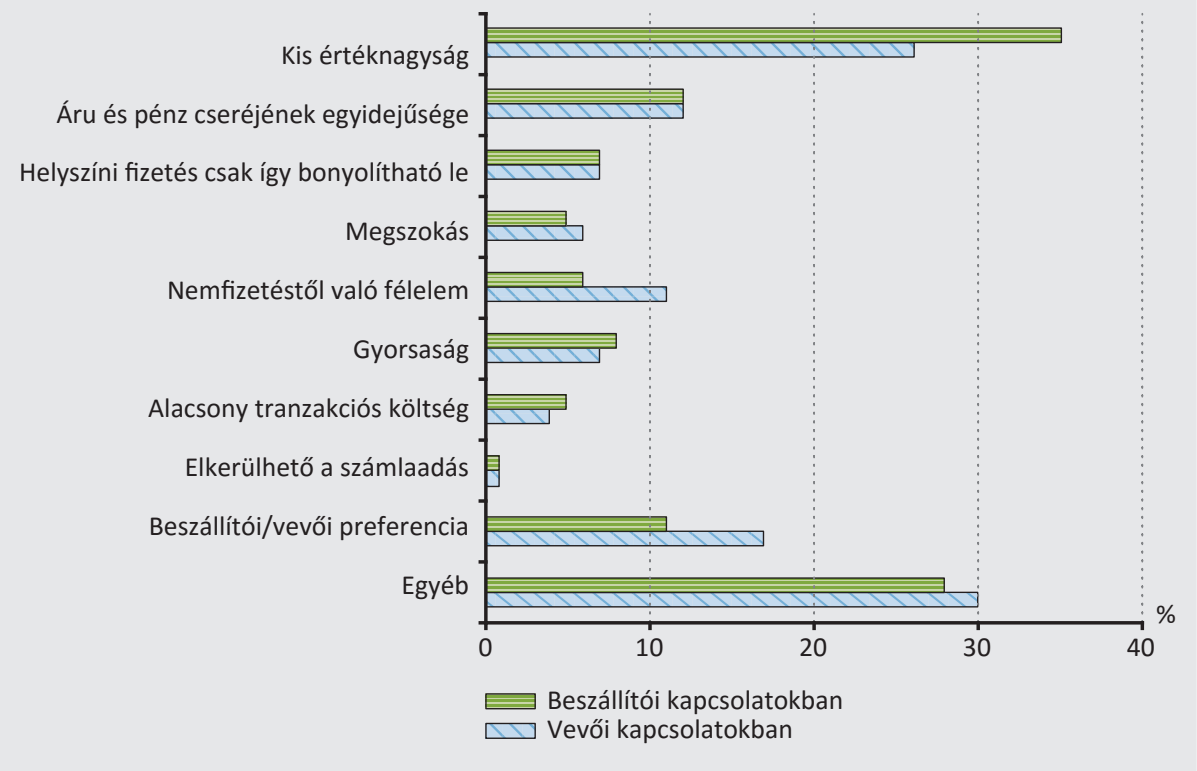

${ }^{9}$ A válaszadók több okot is megjelölhettek a készpénzhasználatra. Mivel a 2013-as és a 2017-es felmérésben nem teljesen ugyanazok az okok szerepeltek, így az eredmények nem hasonlíthatók össze teljes mértékben, ezért az összefoglaló ábrán a 2013-as eredményeket nem jelenítjük meg. 


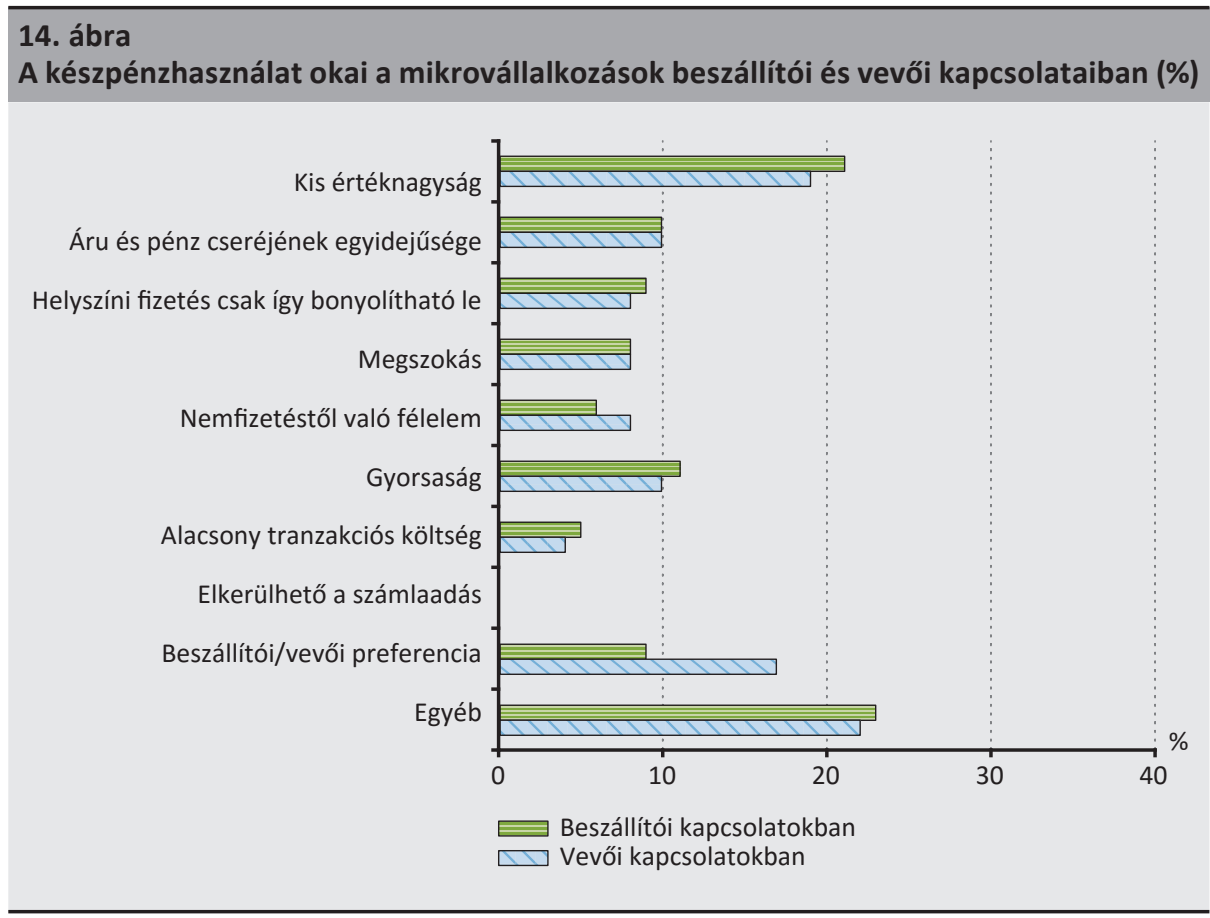

Meg kell jegyeznünk, hogy a válaszadók az eredeti felsorolásban szereplő okok mellett nagy arányban jelölték meg az egyéb kategóriát mint készpénzhasználatra motiváló tényezőt. Az egyéb kategóriát választók által megnevezett okok között viszonylag nagy számban találhatók a vevői preferencia körébe sorolható indokok, igaz, más-más megfogalmazásban (például: „,a magánszemélyek készpénzzel fizetnek”, „,sok vevőnek nincs kártyája”). Ez arra utal, hogy a vevői preferenciára mért értéknél valójában sokkal erősebb a - jellemzően lakossági - ügyfelek részéről mutatkozó igény a készpénzes fizetés alkalmazására. A vevői preferencia azért érdemel külön figyelmet, mert a vállalkozásokhoz a - jellemzően lakossági - vevők irányából rendszeresen, illetve folyamatosan érkező készpénznek továbbgyűrüző hatása lehet, hiszen a készpénzes bevételek - legalábbis részben - a vállalkozások egyes beszerzéseinek kifizetésére fordítódnak, és ezt a készpénzbevételt a beszállító a saját további beszerzései során szintén fizetésre fordíthatja. Ez magyarázatul szolgálhat a beszállítói kapcsolataiban készpénzt használó vállalkozások arányának növekedésére, valamint a beszállítói készpénzes tranzakciók átlagos értékének emelkedésére is. A válaszadók által megnevezett egyéb okok között - a vevői preferenciaként azonosítható okok mellett - leginkább az egyszerúség, a kényelem és az eseti beszerzések könnyebb lebonyolíthatósága jelenik meg.

Külön ki kell még emelni, hogy bár viszonylag kevesen jelölték meg az eredeti felsorolásban a nemfizetéstől való félelmet (a vevői kapcsolatai vonatkozásában a KKV-k 
11, a mikrovállalkozások 8 százaléka), az egyéb okok között viszont többen is megnevezték a bizalmatlanságot, illetve a bizalom hiányát mint készpénzhasználatra motiváló tényezőt. A 2013-as felmérés eredményéhez képest így is jelentős változás tapasztalható ezen a téren, hiszen akkor még a megkérdezett KKV-k 26 százaléka alkalmazott készpénzfizetést azért, mert tartott a vevői nemfizetésétôl. Ez a vállalkozások közötti bizalom, illetve „fair” üzleti magatartás terén jelentős pozitív irányú fejlődésként értelmezhető.

A megszokás mint készpénzhasználatra motiváló tényező is jelentős mértékben visszaszorult 2013-hoz képest. Míg akkor a KKV-k 18 százaléka jelölte meg a készpénzhasználat okaként, addig ez az arány 2017-ben a KKV-k körében mindössze 5 százalék volt a beszállítói kapcsolatokban, és 6 százalék a vevői kapcsolatokban, de a mikrovállalkozások körében is csak 8 százalék mindkét fizetési irányban. Bár csak a vállalkozások elhanyagolható hányada említette a számlaadás elkerülését (és ezáltal az anonimitást) mint a készpénzhasználat okát, feltételezhető, hogy a valós arány ennél magasabb, hiszen a válaszadók valószínúleg névtelenül sem szívesen nyilatkoznak saját jogellenes magatartásukról.

A készpénzhasználat csökkentésére vonatkozó ösztönzőkről a későbbiekben lesz szó, de két tényezőt érdemes lehet már ennél a pontnál is megemlíteni. Mind a KKV-k, mind a mikrovállalkozások jelentős része nyilatkozott úgy, hogy az elektronikus fizetési megoldások költségeinek csökkenése, illetve az elektronikus banki szolgáltatások körének bővülése, rugalmasabbá válása ösztönözné őket leginkább a készpénzhasználat csökkentésére (a megadott ösztönzők közül e kettőt jelölték meg a legtöbben). Ezek az eredmények azt mutatják, hogy a készpénzt használó hazai vállalkozások erösen nyitottak az elektronikus fizetési megoldásokra, ami jelentős elörelépés 2013-hoz képest. A felmérésünk időpontjában rögzített állapot értékelése arra enged következtetni, hogy jelenleg a hitelintézetek által nyújtott elektronikus banki szolgáltatások kínálata nem fedi le és/vagy nem találkozik a vállalatok részéről jelentkező keresleti igénnyel. Ha ezt a rést sikerül csökkenteni, akár már néhány éven belül is jelentős elmozdulás történhet a készpénzmentesen múködő vállalkozások számának növekedése felé.

\subsection{Bizalom(hiány), bizonytalanság, fizetési fegyelem}

A 2013-as felmérés fókuszában a KKV-k közötti üzleti bizalom, illetve annak hiánya, a fizetési magatartás, valamint a készpénzhasználat motivációi közötti összefüggés vizsgálata állt. Az eredmények akkor azt mutatták, hogy a vállalkozások erősen érzékelték az üzleti bizalom, pontosabban a partnerek megbízhatóságának hiányát, amely alapvetően a válság utáni gazdasági környezet bizonytalanságából fakadt, és a legnagyobb problémát a gyenge fizetési fegyelem, a halasztott (határidőn túli) fizetések általánosan elterjedt gyakorlata okozta. A késői fizetésből, illetve az esetleges nemfizetésből adódó kockázatok csökkentése érdekében a vállalkozások rövid fizetési határidőket alkalmaztak, de bevett gyakorlattá vált az azonnali, sőt az előre történő készpénzes fizetés megkövetelése is. A 2017-es felmérés előkészítése során 
felmerült bennünk a kérdés, hogy a válság elmúltával ezen a téren érzékelhetően változott-e a helyzet, ezért ismételten megvizsgáltuk a fizetési fegyelem (fizetési határidők, lejárt, illetve behajthatatlan követelések) és a készpénzhasználat közötti esetleges összefüggés kérdéskörét.

A fizetési határidők nagy gazdasági jelentőséggel bírhatnak, mivel a kis- és középvállalkozások gyakran tudatosan használhatják fel a hosszabb fizetési határidőket, hogy ezáltal jussanak likviditáshoz, különösen, ha nem férnek hozzá egyéb finanszírozási csatornákhoz, például rövidtávú bankhitelekhez. ${ }^{10} \mathrm{~A}$ jelenséget Burkart és Ellingsen (2004) modellezte, melynek alapján Havran et al (2017) empirikusan megmutatta, hogy a 2010-2015 közötti periódusban a magyar vállalkozások mintáján kiegészítő hatás figyelhető meg a rövid lejáratú hitelek és a szállítói tartozások között. McGuiness et al (2018) pedig 13 európai ország KKV-szektorának 2003-2012 közötti adatait vizsgálva arra az eredményre jutott, hogy a szállítói finanszírozáshoz hozzáférő vállalkozások kisebb eséllyel szembesültek pénzügyi problémákkal a gazdasági válság időszakában, amikor a bankhitelhez jutás nehézkesebbé vált. A lazább fizetési határidők tehát segíthetnek abban, hogy a magasabb likviditással rendelkező vállalatok kisegítsék a rövid távon fizetésképtelen vagy finanszírozási problémákkal küszködő társaikat. Ez alapján kijelenthető, hogy hazánkban is kívánatos lenne, hogy a KKV-szektor enyhítsen a 2013-as felmérés alapján szigorúnak mondható fizetési feltételein.

A vállalkozások által jellemzően alkalmazott fizetési határidők tekintetében azonban nem tapasztalható érdemi változás 2013-hoz képest. Jelenleg is a legtöbb vállalkozás (a KKV-knak és a mikrovállalkozásoknak egyaránt 44 százaléka) 8 és 30 nap közötti fizetési határidőt kap a beszállítóitól, illetve a legtöbb (a KKV-k 38 és a mikrovállalkozások 40 százaléka) ugyanilyen határidőt szab a vevői számára is (15. és 16. ábra). A beszállítói oldalon némileg növekedett ugyan a KKV-k mozgástere (a minta alapján enyhén nőtt a 30 napos, a 30 és 60 nap közötti, valamint a 60 és 90 nap közötti fizetési határidővel rendelkezők aránya is, de 95 százalékos konfidenciaszint mellett csak ez utóbbi tekinthető szignifikánsnak). Ez a vevők irányában csak kis részben jelenik meg, mindössze a 30 napos fizetési határidőnél figyelhető meg szignifikáns növekedés.

Az azonnali, egyidejű fizetés terén mérsékelt pozitiv változás figyelhető meg. Kismértékben ugyan, de szignifikánsan csökkent a vevőiktől azonnali fizetést kérő KKV-k aránya (a 2013-as 12 százalékról 8 százalékra), a mikrovállalkozások egy jelentős része (20 százaléka) azonban továbbra is megköveteli vevőitől az azonnali fizetést. Mivel a bankkártyás fizetés alkalmazására csak kevés vállalkozásnál és ritkán kerül sor (ahogy azt az előzőekben láthattuk), nagy bizonyossággal kijelenthető, hogy az azonnali fizetések igen jelentős részben készpénzben teljesülnek.

\footnotetext{
${ }^{10}$ Az ilyen típusú finanszírozás a nemzetközi szakirodalomban „trade credit” néven ismert.
} 


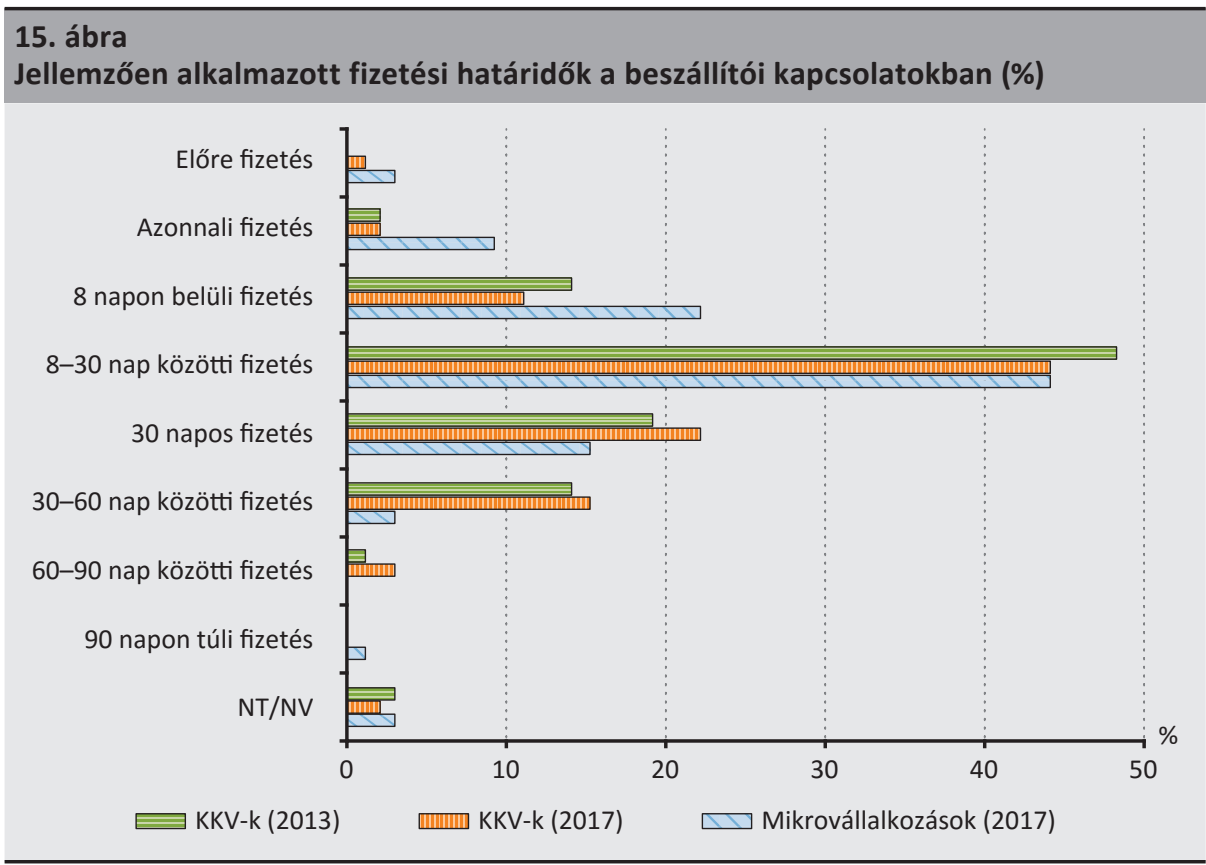

16. ábra

Jellemzően alkalmazott fizetési határidők a vevői kapcsolatokban (\%)

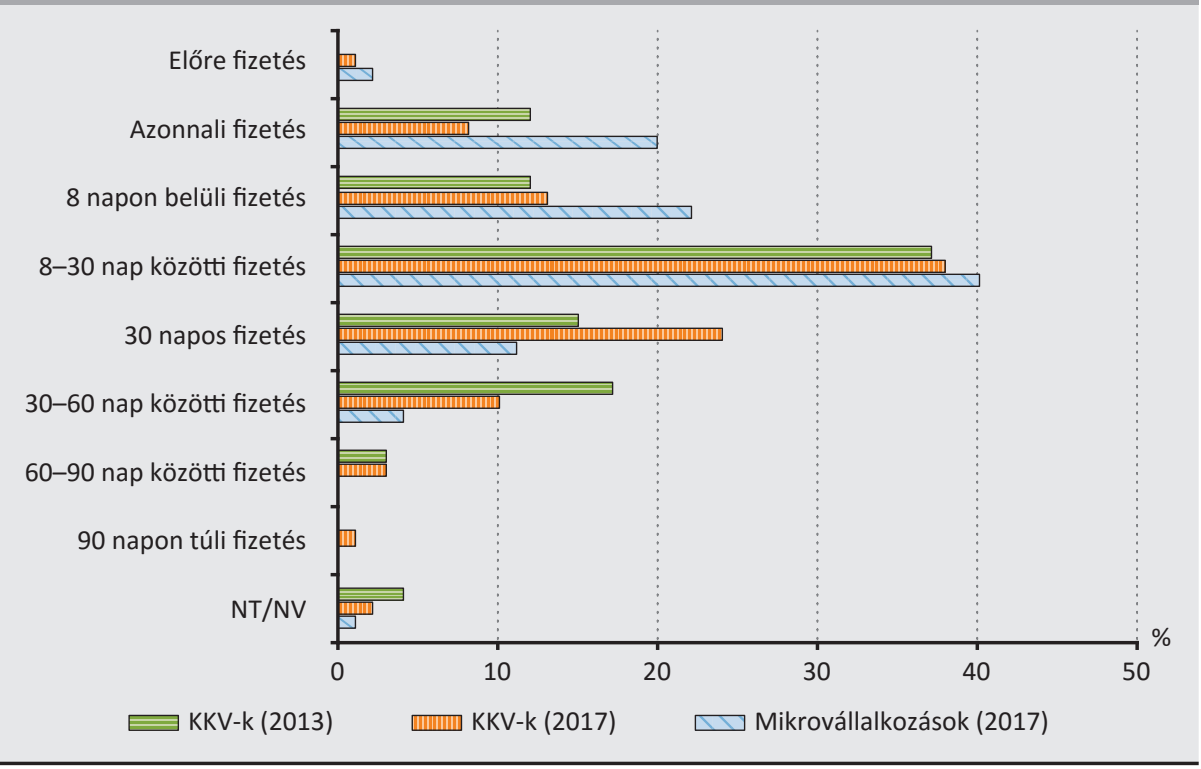


Ahogy az az ábrákon látható, a mikrovállalkozások lényegesen szigorúbb fizetési határidőkkel szembesülnek a beszállítói kapcsolataikban, mint a KKV-k, és ettől nyilván nem független, hogy a vevői irányban is ők szabnak meg rövidebb határidőket. A lejárt, illetve behajthatatlan tartozások vizsgálatának eredménye ezt a megkülönböztetést nem indokolja, így a beszállítók által a mikrovállalkozások számára megszabott szigorúbb fizetési feltételek sokkal inkább a gyengébb alkupozícióiknak, mint a fizetési hajlandóságukkal szembeni bizalmatlanságnak tudható be.

A mikrovállalkozások a KKV-knál kisebb részben (10 százalékuk, szemben a KKV-k 21 százalékával) nyilatkoztak úgy, hogy jelenleg van lejárt tartozásuk a beszállítóik felé. A vevői oldalról megvizsgált lejárt, illetve behajthatatlan követelések ennél kedvezőtlenebb képet mutatnak (a KKV-k 60 százalékának van lejárt követelése, és 48 százalékuknak volt az elmúlt három évben behajthatatlan követelése, ugyanezek az arányok a mikrovállalkozások esetében 28, illetve 31 százalék). Ez alapján feltételezhető, hogy a felmérésben részt vevők a saját fizetési magatartásukat a valóságosnál némileg kedvezőbb színben tüntették fel, de ez a jelenség mindkét vállalkozási csoportban egyaránt előfordulhat, így nincs okunk feltételezni, hogy a KKV-k a mikrovállalkozásoknál megbízhatóbban teljesítenék fizetési kötelezettségeiket.

Ha összehasonlítjuk a 2013-as kutatás eredményeit jelenlegi adatainkkal (17. ábra), a lejárt, illetve behajthatatlan tartozásokkal kapcsolatos kérdésekre adott válaszokból megállapítható, hogy a fizetési fegyelem a KKV-szektorban egyértelmüen javult. Míg 2013-ban a válaszadók közel felének volt lejárt követelése, ez az arány 2017ben már kevesebb mint 20 százalék, s leginkább a kis összegú (1 millió Ft alatti) tartozások aránya csökkent.

A behajthatatlan követelésekkel kapcsolatos válaszok szintén alátámasztják a fizetési fegyelem javulását. A 2013-as, illetve a 2017-es felmérés eltérő skálázása miatt a követelések nagysága közvetlenül nem hasonlítható össze, az azonban megállapítható, hogy a 2017-es válaszadóink fele nem szembesült behajthatatlan tartozással az elmúlt 3 évben, szemben a 2013-as 35 százalékkal (18. ábra).

Összegezve a fizetési határidők betartására, valamint a kintlévőségek és behajthatatlan követelések összegére és nagyságrendjére vonatkozó válaszokat elmondhatjuk, hogy a KKV-szektorban jelentösen javult a vállalkozások üzleti környezete és ezzel együtt a fizetési fegyelem. Ez az elmozdulás nagyon lényeges a müködőképesség és a versenyképesség szempontjából, hiszen teret engedhet a vállalati növekedésnek, alapozva a vállalati müködési, likviditási feltételek javulására. 
17. ábra

Lejárt követelések értéke 2013-ban, valamint 2017-ben a megkérdezett KKV-k körében

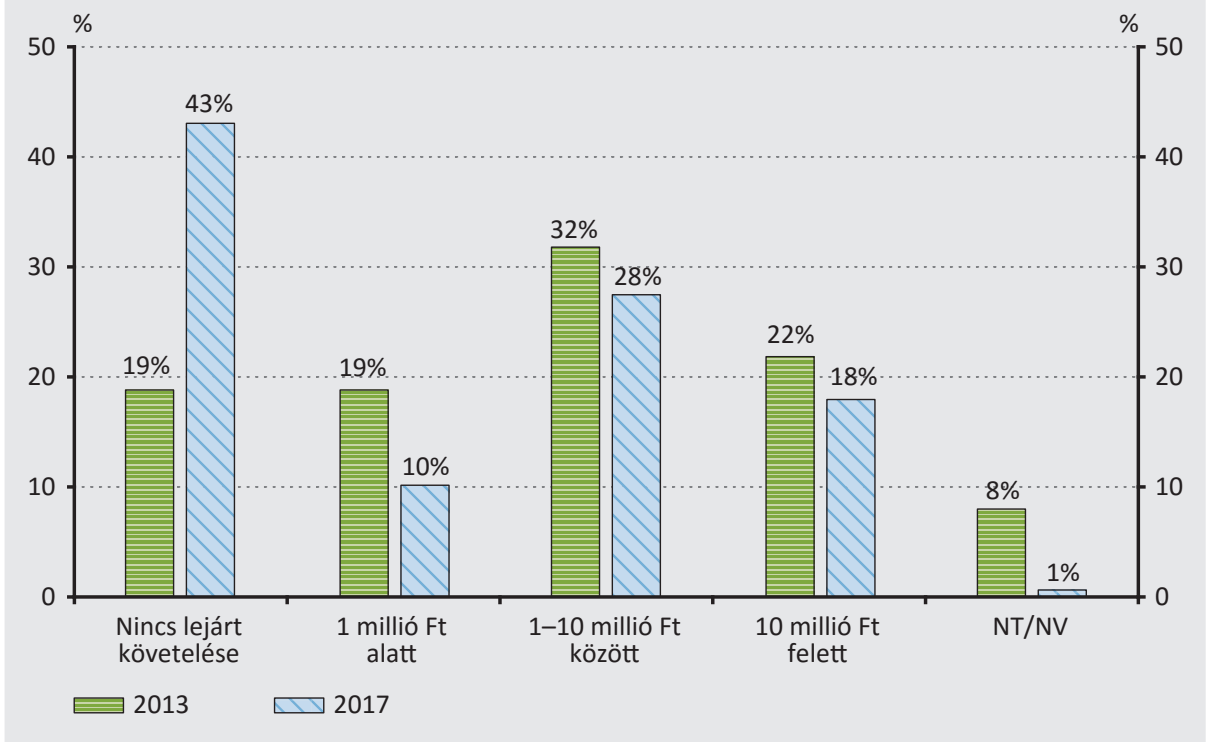

18. ábra

Volt-e behajthatatlan követelése az elmúlt 3 évben? A KKV-k által adott 2013-as és 2017-es válaszok összehasonlítása

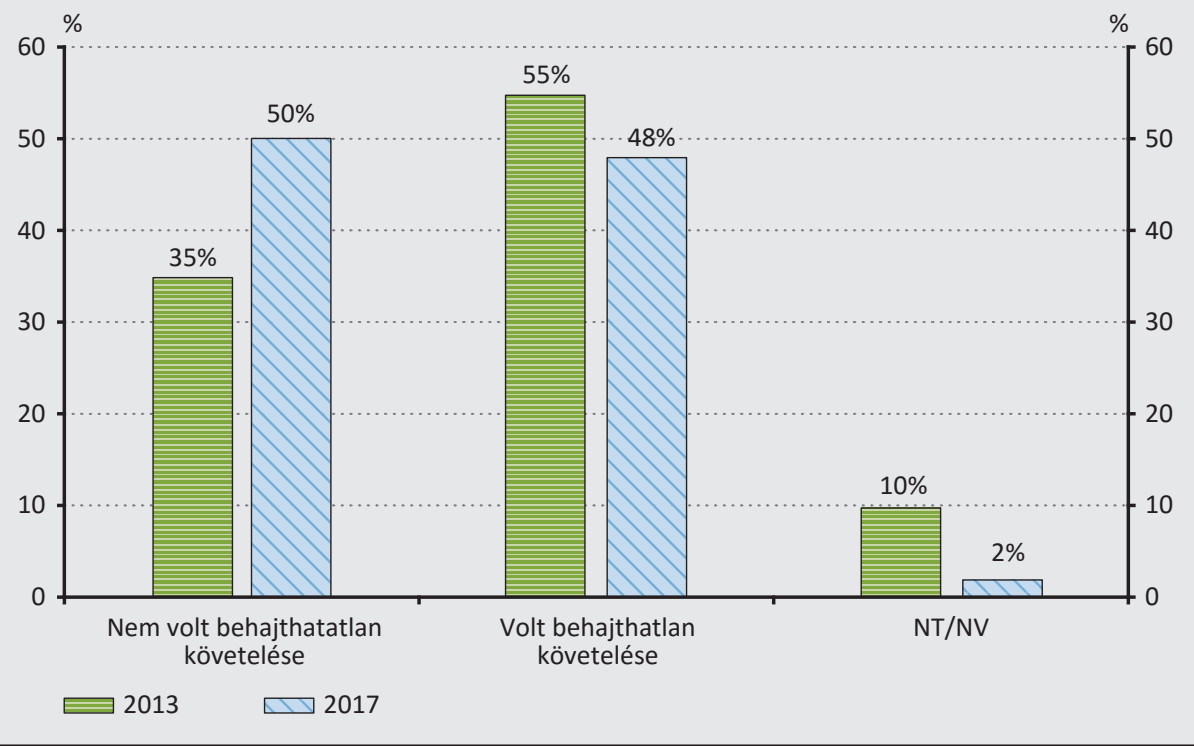


Az Intrum Justitia nemzetközi követeléskezelő által publikált European Payment Report 2017 címú tanulmány szerint Magyarországon a fizetési fegyelem nemzetközi összehasonlításban általánosan jónak mondható. Bár 29 európai országot lefedő felmérésükben nem csupán kis-, közép- és mikrovállalkozásokat kérdeztek meg, eredményeik számunkra is hasznos tanulságokkal szolgálhatnak. Tanulmányuk szerint az átlagos fizetési határidő üzleti (B2B) tranzakciók esetén 26-27 nap, fogyasztók felé 11-14 nap, az állami szektorban pedig 27 nap, ezen értékek valamivel kedvezőbbek az európai átlagnál. A magyar vállalkozások éves bevételeik 2,1 százalékát kénytelenek behajthatatlan tartozásként elkönyvelni, ami pontosan megegyezik a teljes Európára mért aránnyal.

A tanulmány legfontosabb megállapításai a magyarországi helyzetre vonatkozóan az alábbiakban foglalhatóak össze. Hazánkban általánosan elfogadott, hogy a vállalkozások vevői kérésre a számukra ideálisnál hosszabb fizetési határidőket is engedélyeznek. A válaszadók 58 százalékára jellemző, hogy egyéb kikötések nélkül belemegy a fizetési feltételek enyhítésébe, ez az arány pedig európai viszonylatban kifejezetten magas. A késedelmes fizetések leggyakoribb oka Magyarországon az adósok pénzügyi nehézsége. Az elszámolási viták vagy adminisztrációs problémák kevéssé jellemzőek. A megkérdezettek 40 százaléka szerint a lejárt tartozások valamiIyen mértékben akadályozzák vállalkozását a növekedésben, 24 százalékuk pedig úgy véli, több alkalmazottat tudna foglalkoztatni, ha ügyfelei mindig időben fizetnének.

Összességében tehát kijelenthető, hogy a hazai vállalati szférában jelenleg nincs jelen az európai átlagot meghaladó mértékủ bizalomhiány, sőt, bizonyos mutatók alapján arra is következtethetünk, hogy a magyar vállalkozások átlagon felüli bizalommal rendelkeznek vevőik irányában. Felmérésünk alapján a megszabott átlagos fizetési határidőkben csak enyhe lazulás figyelhető meg, azonban mind a késedelmes fizetések, mind pedig a behajthatatlan tartozások aránya csökkenő tendenciát mutat. Mindezeket figyelembe véve 2017-ben már nem túnik helytállónak az a kijelentés, hogy a hazai KKV-k és mikrovállalkozások továbbra is nagyarányú készpénzhasználata mögött fő motivációs faktorként az üzleti bizalom általános hiánya állna.

\subsection{Hitelintézeti preferenciák, bankváltás}

A felmérés során vizsgáltuk azt is, hogy a hazai vállalkozások milyen szempontok alapján választanak számlavezető pénzintézetet, illetve váltottak-e bankot az elmúlt 3 évben, és ha igen, ez milyen okok miatt történt. Ezzel elsősorban azt kívántuk ellenőrizni, hogy a készpénzhasználat mögöttes okai között szerepel-e a banki szolgáltatásokkal, illetve azok költségeivel szembeni elégedetlenség.

Eredményeink szerint a felmérésben részt vevő vállalkozások nagyon lojálisak a számlavezető pénzintézetükhöz, mivel csak mintegy 15 százalékuk váltott bankot az elmúlt években. Ez az arány közelítóleg megegyezik a KKV-k és mikrovállalkozások esetében. A KKV-k esetén a csere elsődleges indokai a költségtakarékosság, 
valamint a kényelmesebb, jobban igényekre szabott kiszolgálás, illetve a kedvezőbb pénzügyi szolgáltatáscsomag nyújtása (pl. számlavezetési feltételek, hitelfelvétel) voltak. Az elmúlt 3 évben bankot váltó válaszadók közel felét (46 százalék) előbbi, nagyjából harmadát (30 százalék) pedig utóbbi szempont motiválta korábbi számlavezető pénzintézetének lecserélésében. Emellett a váltás indokaként kisebb mértékben megjelent még a korábbi pénzintézettel szembeni elégedetlenség, valamint nem elhanyagolható mértékben fordult elő a bank megszúnése vagy csődje miatti kényszerű csere is.

A mikrovállalkozások esetén a bankváltás fő oka legtöbb esetben szintén a költségtakarékosság, valamint a jobb kiszolgálás és a kedvezőbb pénzügyi szolgáltatáscsomag volt, az arányok azonban mindkét indok esetén elmaradnak a KKV-kra jellemző mutatóktól (33 százalék, illetve 22 százalék). A KKV-khoz képest nagyobb arányban jellemző viszont a korábbi pénzintézet csődje, vagy megszűnése miatti kényszerű bankváltás (20 százalék), illetve fontosabb tényezőként jelenik meg a bankfiók közelsége is. Az elmúlt 3 évben bankot váltó mikrovállalkozók 11 százaléka jelölte meg a korábbi számlavezető pénzintézet legközelebbi fiókjának bezárását a csere indokaként (19. és 20. ábra).

\section{9. ábra \\ Az elmúlt 1-3 évben számlavezető bankot váltó KKV-k aránya, valamint a váltás fő indoka (\%)}

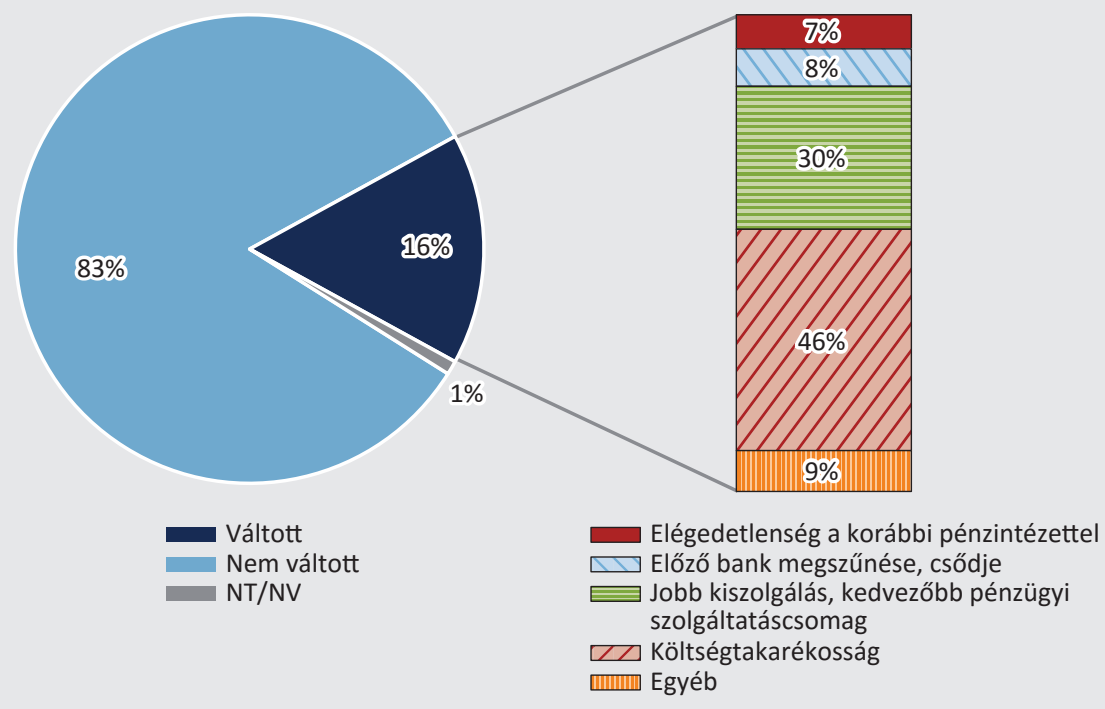




\section{0. ábra}

Az elmúlt 1-3 évben számlavezető bankot váltó mikrovállalkozások aránya, valamint a váltás fö indoka (\%)

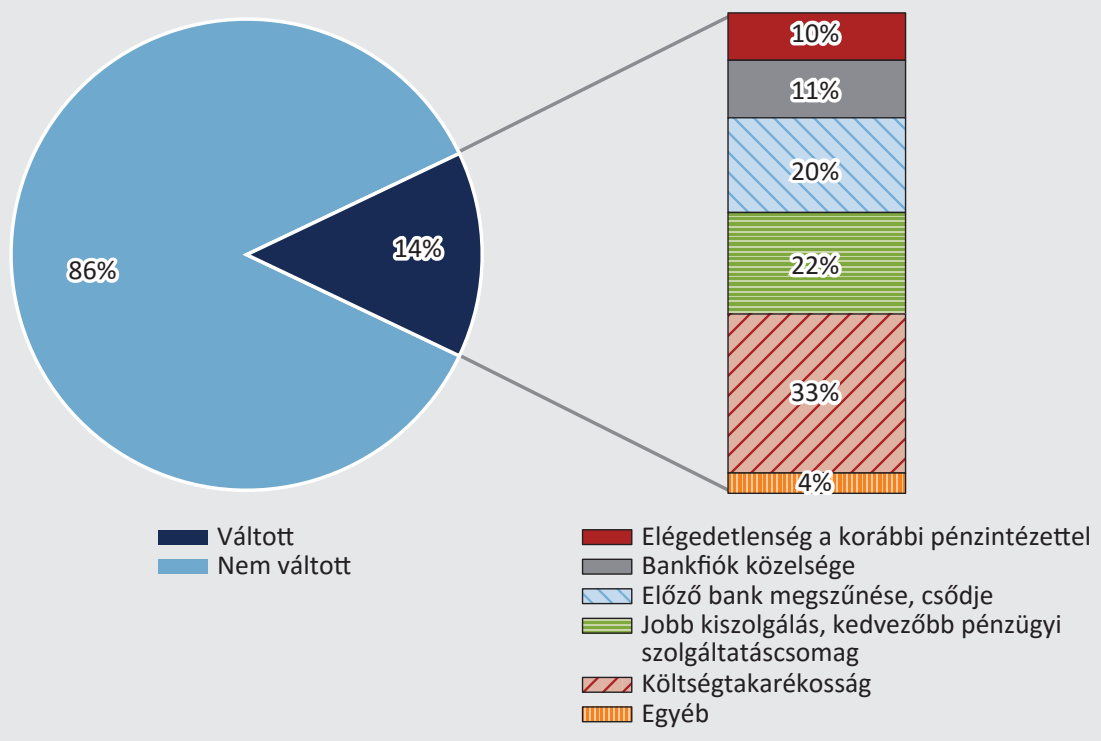

A felmérésben részt vevőket a bankváltás másodlagos okairól is kérdeztük, melyre tetszőleges számú választ jelölhettek meg. Mind a KKV-k, mind pedig a mikrovállalkozások esetében a válaszadók nagyjából fele adott meg legalább egy másodlagos indokot. A legjellemzőbb mindkét vállalkozási forma esetén a jobban igényekre szabott kiszolgálás, illetve a kedvezőbb pénzügyi szolgáltatáscsomag nyújtása volt. Emellett előfordult még válaszként a költségtakarékosság, a korábbi számlavezető pénzintézettel szembeni elégedetlenség, valamint az új bank fiókjának jobb elérhetősége (közelség, nyitvatartás).

A két kérdésre adott válaszokat összesítve megkaphatjuk, hogy egy adott szempont a bankot váltó vállalkozások hány százalékánál játszott szerepet a döntésben (21. ábra). Eredményeink alapján összességében elmondható, hogy a bankváltás legjellemzőbb motivációi a költségtakarékosság, valamint a személyre szabott kiszolgálás és a kedvezőbb pénzügyi szolgáltatáscsomag. Ezen szempontok a KKV-k esetén fontosabbak, esetükben a döntések nagyjából 60 százalékában, míg a mikrovállalkozások 40 százalékában játszottak szerepet. Érdemes kiemelni, hogy a válaszok alapján a bankváltás csak az esetek mintegy 20 százalékában társul a korábbi pénzintézettel való elégedetlenséggel. A KKV-k esetén 80 bankot váltó válaszadóból 17 jelölte meg ezt akár elsődleges, akár másodlagos szempontként, míg ugyanez az arány a mikrovállalkozások esetén 72-ből 13. A bankfiókok közelsége, elérhetősége inkább a mikrovállalkozások számára jelenthet indokot a számlavezető pénzintézet lecserélésére, a releváns válaszadók 21 százaléka vette figyelembe ezt a szempontot. 


\section{1. ábra}

Az elmúlt 1-3 évben bankot váltó válaszadók mekkora része vette figyelembe az adott szempontot (\%)

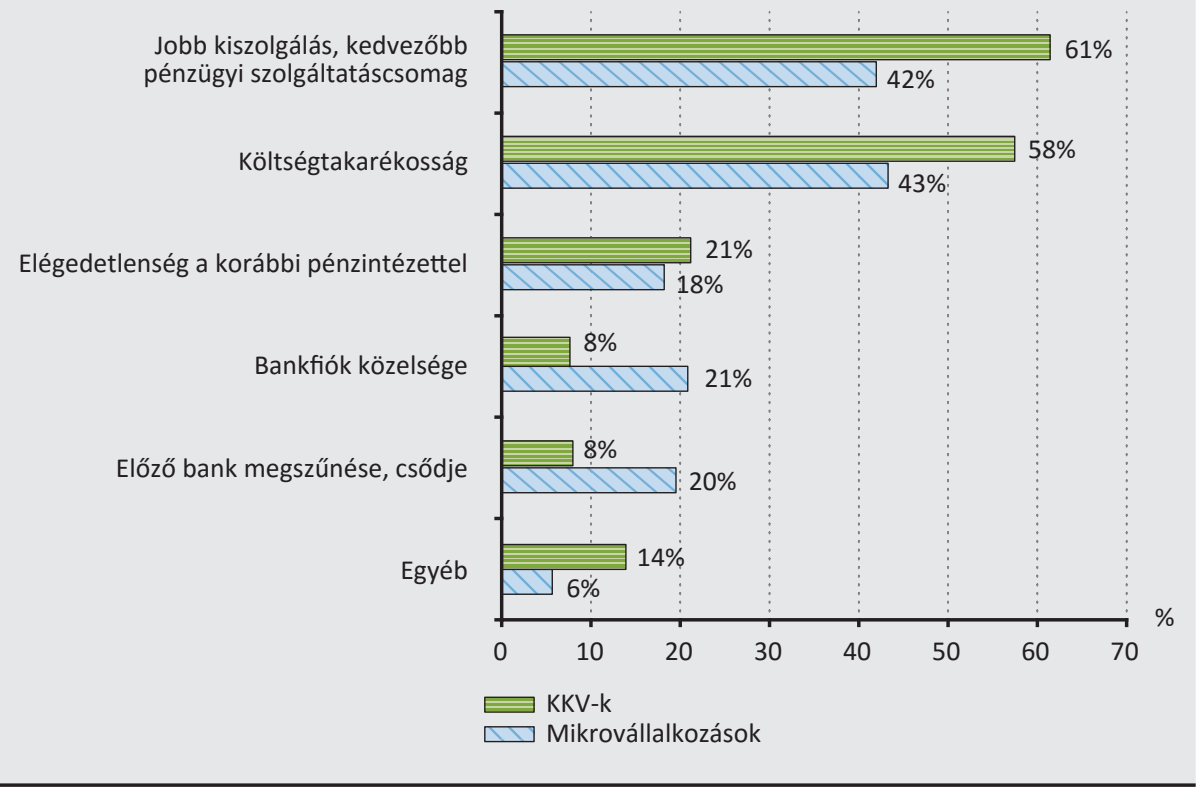

A vállalkozások bankválasztási preferenciáit egy további kérdéssel is vizsgáltuk, melyben a válaszadóknak öt, a bankfiókok elérhetőségével kapcsolatos állítás közül kellett kiválasztani azt, amellyel leginkább egyetértenek (22. ábra). A legnépszerűbb állítás mind a KKV-k, mind pedig a mikrovállalkozások között az volt, mely szerint „Csak olyan pénzintézetet választok, amelynek van a székhelyemhez/telephelyemhez közeli fiókja". A mikrovállalkozások 45 százaléka választotta ezt az állítást, míg a KKV-k közül valamivel kevesebben, a válaszadók 35 százaléka, mely alátámasztja azon korábbi állításunkat, hogy a mikrovállalkozások számára fontosabb szempont a bankfiókok közelsége. Szintén ezen állításunkat erősíti, hogy a KKV-k 12 százaléka hajlandó távolabbi fiókot választani kedvezőbb díjakért vagy feltételekért cserébe, míg a mikrovállalkozások között kisebb, 8 százalékos ez az arány. 


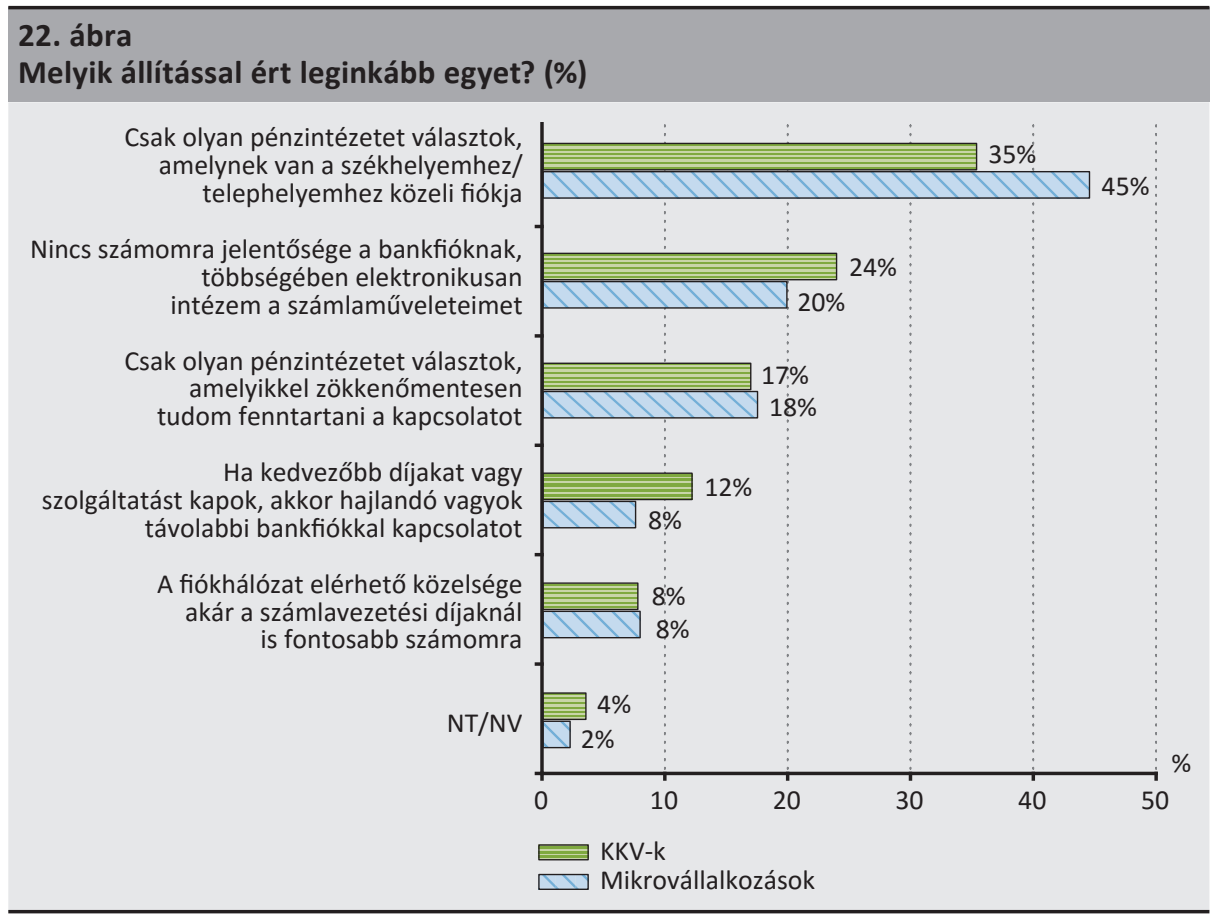

Mindkét vállalkozási forma esetén a válaszadók 8 százaléka kritikus fontosságúnak tartja a bankfiókok elérhetőségét, és ennek érdekében akár magasabb számlavezetési díjat is hajlandó fizetni. Ennél többen állítják viszont, hogy nincs jelentősége számukra a bankfióknak, mivel számlamúveleteiket többnyire elektronikusan intézik (KKV-k: 24 százalék, mikrovállalkozások: 20 százalék). Nagyjából megegyezik azok aránya, akik számára a bankfiókkal való zökkenőmentes kapcsolattartás a legfontosabb, melyhez nem feltétlenül szükséges, hogy a fiók földrajzilag közel helyezkedjen el a vállalkozás székhelyéhez vagy telephelyéhez. (KKV-k: 17 százalék, mikrovállalkozások: 20 százalék).

Felmérésünk során arra is kíváncsiak voltunk, hogy a válaszadók jellemzően milyen típusú ügyleteket bonyolítanak le abban az esetben, ha felkeresik számlavezető bankfiókjukat (23. ábra). Mind a KKV-k, mind pedig a mikrovállalkozások legjellemzőbb bankfióki tevékenysége a készpénz ki-, illetve befizetése, 70 százalék körüli azok aránya, akik ilyenkor pénzt fizetnek be számlájukra, vagy vesznek föl onnan. A KKV-k esetén gyakori emellett a hitelügyintézés, valamint az egyéb számlamúveleti tevékenységek (pl. jogosultságok kezelése): mindkettőt a válaszadók közel 40 százaléka jelölte meg. Az elóbbi két ügylettípus a mikrovállalkozások esetén is hangsúlyos, azonban valamivel kisebb mértékben, 20, illetve 27 százalékos aránnyal van jelen. A mikrovállalkozások esetén emellett a válaszadók több mint 20 százaléka szokott bankfiókja felkeresése esetén papíralapon átutalást kezdeményezni. 
Összességében kijelenthetö, hogy a magyar KKV-k és mikrovállalkozások nagyon erösen lojálisak bankjaikkal, hiszen a kényszerü bankváltásokat nem számítva az elmúlt 3 évben alig több, mint 10 százalékuk cserélte le számlavezető pénzintézetét. A bankváltás elsődleges okaként a legtöbb válaszadó a költségtakarékosságot jelölte meg, de mégsem állíthatjuk, hogy a hazai vállalkozások kiemelten költségérzékenyek lennének, hiszen többségük a bank által nyújtott szolgáltatások minőségét is figyelembe veszi döntése meghozatalához.

\section{3. ábra \\ Milyen típusú ügyleteket bonyolít le, ha felkeresi számlavezető bankfiókját? Az egyes ügylettípusok gyakorisága (\%)}

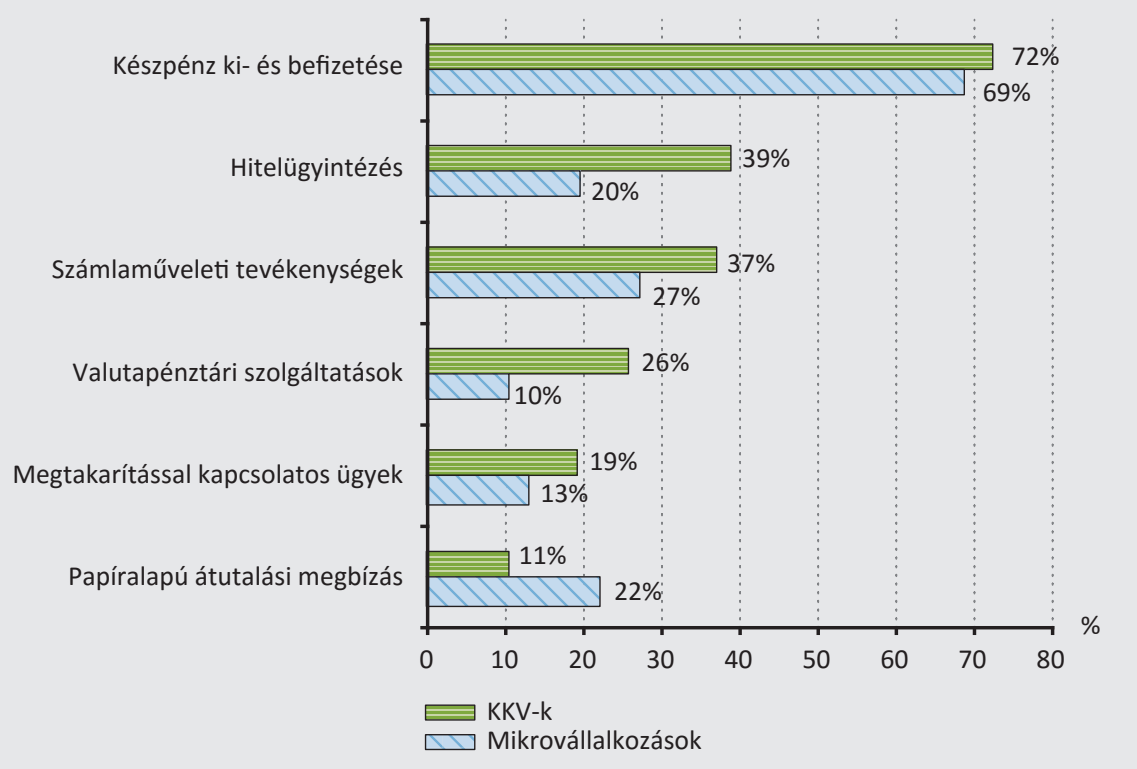

Fontos üzenete a felmérésnek az is, hogy a KKV-szektorban pénzforgalmi szempontból csökken a bankfiókok jelentősége, csak a válaszadók nagyjából 40 százaléka nyilatkozta, hogy fontos számára a könnyen elérhető fiókhálózat. Ezzel szemben azonban a mikrovállalkozások több mint felének még mindig kulcsfontosságú szempont bankválasztás esetén, hogy a számlavezető pénzintézet rendelkezzen megfelelően közeli fiókkal. A legjellemzőbb bankfiókban végzett tevékenység egyértelműen a készpénz ki- és befizetése, emellett a vállalkozások például hitelügyintézés, vagy egyéb számlaműveletek elvégzése miatt keresik fel bankjukat, valamint a mikrovállalkozások esetén továbbra is viszonylag gyakori az átutalások papíralapú kezdeményezése. 


\subsection{Hogyan lenne csökkenthető a vállalkozások készpénzhasználata?}

A felmérésben részt vevőket megkérdeztük, hogy mi jelentene ösztönzést számukra a készpénzes múveletek elektronikus fizetési megoldásokkal történő helyettesítésére. Bár a vállalkozások meglehetősen jelentős aránya (a KKV-k 31, a mikrovállalkozások 20 százaléka) nyilatkozott úgy, hogy nem tartja fontosnak a készpénzhasználat csökkentését, ezért nem is foglalkozik ezzel a kérdéssel, a többségnél - elsősorban pozitív ösztönzők hatására - elérhető lenne a készpénz használatának visszaszorítása. A megadott lehetőségek közül a válaszadók többet is megjelölhettek, illetve az interjúk során saját szavaikkal egyéb ösztönzőket is megfogalmazhattak. A vállalkozások leginkább az elektronikus fizetési megoldások költségeinek csökkentésére, valamint az elektronikus banki szolgáltatások bővülésére, rugalmasabbá válására lennének nyitottak (24. ábra). Ezek a lehetőségek valójában az ábrában szereplőnél is nagyobb arányban ösztönözhetnék a vállalkozásokat, tekintve, hogy az egyéb kategóriát választók által megnevezett ösztönzők között is nagyszámban szerepeltek ezekbe a kategóriákba sorolható javaslatok (pl. „olcsóbb lenne a banki átutalás”, „technikai javulás a bankok részéről”, „gyorsabb lenne a négy órás átutalás, akár azonnali”, „tranzakciós adók átszabása”).

Fontosnak tartjuk kiemelni, hogy a kutatási eredményeink szerint a készpénzes tranzakciók költségeinek esetleges emelkedése sokkal kevésbé lenne hatásos és eredményes a készpénzhasználat visszaszorítása érdekében folytatott küzdelemben, mint a pozitiv ösztönzök. Kevesebb mint feleannyian (a KKV-k 29, a mikrovállalkozások 25 százaléka) gondolják úgy, hogy a készpénzes múveletek költségeinek növekedésére visszaszorítanák a készpénzhasználatot, mint ahányan ugyanezt tennék az elektronikus fizetési megoldások költségeinek csökkenése esetén (a KKV-k 62, a mikrovállalkozások 55 százaléka).

Azon válaszadókat, akikre egyszerre teljesül, hogy fizetéseikhez számottevő arányban használnak készpénzt, valamint fontosnak tartják a készpénzhasználat visszaszorítását, jellemzően az elektronikus fizetés költségeinek csökkentése motiválná erre leginkább. Nem teljesül azonban rájuk, hogy ennek érdekében az elmúlt 3 évben nagyobb arányban váltottak volna számlavezető pénzintézetet, mint a teljes minta. Cikkünkben - föként a releváns minta kis elemszáma miatt - nem áll módunkban annak részletesebb elemzése, hogy a fentebb leírt csoportba tartozó vállalkozások milyen egyéb közös jellemzőkkel rendelkeznek, ennek megismerése azonban fontos eleme lehet további kutatásoknak, hiszen nagymértékben segítheti a kényszerű készpénzhasználat csökkentését. 


\section{4. ábra \\ A készpénzhasználat csökkentésének ösztönzőire való fogékonyság a vállalkozások körében (\%)}

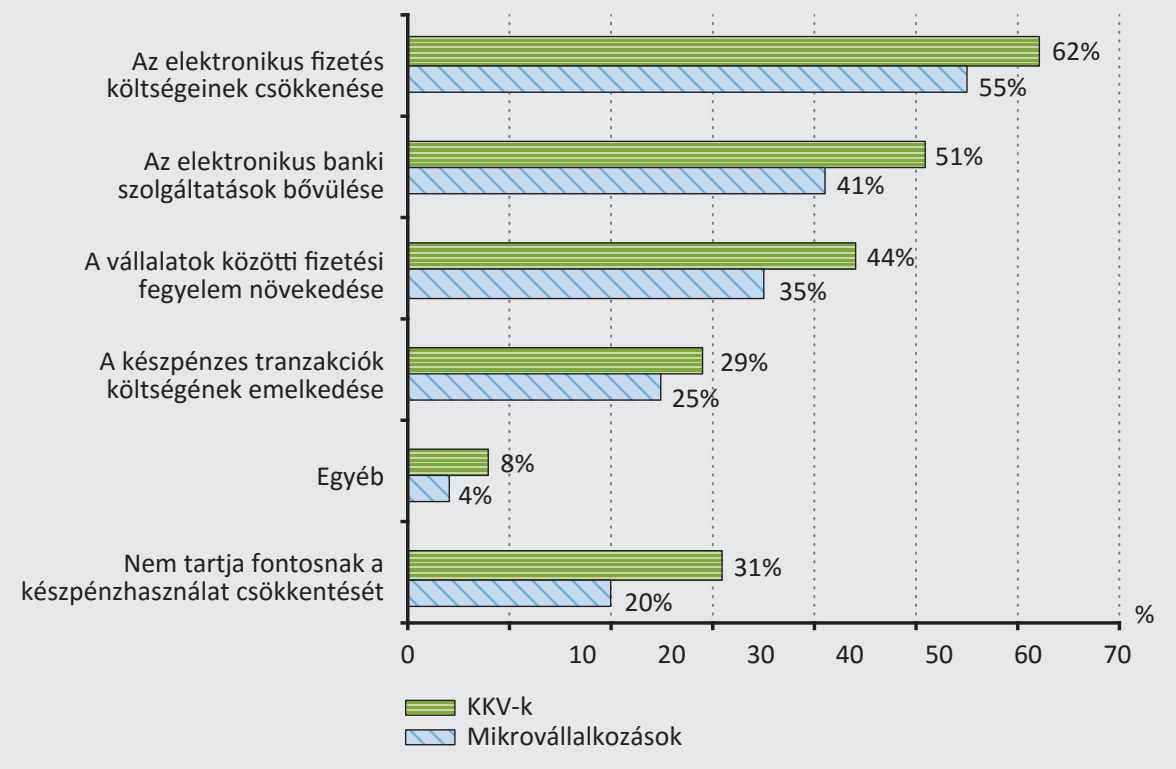

Feltételezhető, hogy a vállalati készpénzhasználat preferálása összefüggésben állhat a rejtett gazdaság jelenlétével is. Jelen felmérésünk céljai között azonban nem szerepelt e kapcsolat részletesebb vizsgálata, erre az általunk használt módszertan sem ad lehetőséget. A témával magyar és külföldi szerzők részletesen foglalkoztak (például Rogoff 1998, Bajada - Schneider 2005, Semjén et al 2009), és igazolták a kapcsolatot, hogy a rejtett gazdaság működésének a készpénz egyik szükséges eleme.

\subsection{Készpénzhasználati összefüggések}

Bár mintánk kis elemszáma kevésbé ad lehetőséget összetett statisztikai elemzésekre, mégis kísérletet teszünk regresszióbecsléssel annak megállapítására, hogy az általunk vizsgált szempontok közül melyek befolyásolják leginkább a vállalkozások kézpénzhasználatát (külön-külön a kis- és közép-, valamint a mikrovállalkozások esetében). Mivel a vevőkkel folytatott tranzakciók során a fizetés módjának kiválasztásában feltehetően nem csupán vállalati szempontok, hanem a vevői preferenciák is szerepet játszanak, a vállalkozások készpénzhasználatát a továbbiakban elsősorban a beszállítói kapcsolatok adataira szorítkozva vizsgáljuk. Külön elemezzük, hogy milyen jellemzők vannak hatással egy vállalkozás készpénzmentességére, valamint a készpénzt használó vállalkozások esetén annak arányára, mivel feltételezésünk szerint e két jelenség hátterében bizonyos mértékig eltérő összefüggések állhatnak. 
A készpénzt használó vállalkozások esetén becsült regressziónk függő változója a készpénzes fizetések százalékos aránya a vállalkozás beszállítói kapcsolataiban, magyarázó változói pedig a mikrovállalkozások esetén a készpénzes fizetések százalékos aránya az adott vállalkozás vevőkapcsolataiban, a 2016-os árbevételt kategorizáló dummy változók (referenciaként a legnagyobb elemszámú csoportot felhasználva), valamint egy további dummy változó, melynek értéke 1, ha a válaszadó az elmúlt 3 évben számlavezető bankot váltott. A KKV-szektor esetében magyarázó változóként szerepel két további dummy változó, melyek azt írják le, hogy a válaszadó saját megítélése szerint a napon belüli átutalás, valamint a tranzakciós illeték bevezetése hatással volt-e vállalkozása múködésére (az ezekre vonatkozó kérdések csak a kis- és középvállalkozások képviselői által kitöltött kérdőívekben szerepeltek).

1. táblázat

A KKV-szektor és a mikrovállalkozások készpénzhasználatát magyarázó regressziók becsült együtthatói

\begin{tabular}{|c|c|c|c|}
\hline \multicolumn{2}{|l|}{ KKV-szektor } & \multicolumn{2}{|l|}{ Mikrovállalkozások } \\
\hline $\begin{array}{l}\text { Készpénzes fizetés aránya } \\
\text { a vevőkapcsolatokban (\%) }\end{array}$ & $0,29 *$ & $\begin{array}{l}\text { Készpénzes fizetés aránya } \\
\text { a vevőkapcsolatokban (\%) }\end{array}$ & $0,56^{*}$ \\
\hline \multicolumn{2}{|l|}{ 2016-os árbevétel (200-500 millió Ft) } & \multicolumn{2}{|l|}{ 2016-os árbevétel (0-25 millió Ft) } \\
\hline 0-100 millió Ft & $19,53 *$ & 25-50 millió Ft & $-11,16^{*}$ \\
\hline 100-200 millió Ft & $8,85^{*}$ & 50-100 millió Ft & $-15,50 *$ \\
\hline 500-1000 millió Ft & $-0,21$ & 100 millió Ft felett & $-23,99 *$ \\
\hline 1000 millió Ft felett & $-7,78^{*}$ & $\begin{array}{l}\text { Az elmúlt } 3 \text { évben váltott számlavezető } \\
\text { bankot }\end{array}$ & $7,07^{*}$ \\
\hline $\begin{array}{l}\text { A napon belüli átutalás bevezetése } \\
\text { hatással volt a vállalkozás múködésére }\end{array}$ & $-6,41^{*}$ & Konstans & $20,68^{*}$ \\
\hline $\begin{array}{l}\text { A tranzakciós illeték bevezetése hatással } \\
\text { volt a vállalkozás múködésére }\end{array}$ & 2,78 & $\mathrm{~N}$ & 273 \\
\hline $\begin{array}{l}\text { Az elmúlt } 3 \text { évben váltott számlavezető } \\
\text { bankot }\end{array}$ & 6,27 & $\mathrm{R}^{2}$ & 0,50 \\
\hline Konstans & $11,44^{*}$ & & \\
\hline $\mathrm{N}$ & 263 & & \\
\hline $\mathrm{R}^{2}$ & 0,41 & & \\
\hline
\end{tabular}

A modell esetén felmerülhet a multikollinearitás gyanúja, hiszen azok a tényezők, amelyek szignifikánsak a beszállítói oldali készpénzhasználat tekintetében, összefügghetnek a vevői készpénzhasználattal is. A VIF-mutatók ${ }^{11}$ értéke azonban valamennyi változó esetén 2 alatti, így torzító hatásokkal nem kell számolnunk.

${ }^{11}$ Variance Inflation Factor: megmutatja, hogy az adott változó becsült együtthatójának tényleges varianciája hányszorosa annak, ami a multikollinearitás teljes kizárásával lenne. 
Az 1. táblázatban szereplő együtthatók alátámasztják azon korábbi feltételezésünket, miszerint a vevői oldalról befolyó készpénz továbbgyűrűzik a beszállítói kapcsolatok felé, különösen a mikrovállalkozások esetén. Emellett mind a kis- és közép-, mind pedig a mikrovállalkozások körében igaz, hogy minél nagyobb árbevétellel rendelkezik egy vállalat, annál kisebb arányban használ készpénzt beszállítói felé. A szabályozói intézkedésekkel kapcsolatban elmondható továbbá, hogy azon válaszadók esetén, akik szerint a napon belüli átutalás hatással van vállalati múködésükre, átlagosan 6,41 százalékponttal kisebb a készpénzes tranzakciók aránya. A mikrovállalkozások esetén azoknál, akik az elmúlt 3 évben lecserélték számlavezető bankjukat, nagyobb a készpénzes tranzakciók aránya a beszállítók felé, ez áttételesen arra utalhat, hogy esetükben a készpénzhasználat hátterében az elektronikus fizetési megoldások magas költségei állhatnak. A felmérésünkben vizsgált egyéb jellemzők (pl. alkalmazottak száma, fő tevékenység, fizetési határidők, számlavezetési költségek megváltozása az elmúlt években) és a vállalkozások készpénzhasználatának aránya között szignifikáns kapcsolat nem volt megfigyelhető, így a fentebb közölt modell ezeket nem tartalmazza.

Azt, hogy bizonyos tényezők mennyiben befolyásolják a beszállító oldali készpénzmentességet, logisztikus regresszióval vizsgáltuk, mivel a függő változó két értéket vehet fel (1: készpénzmentes vagy 0: készpénzt használó). A magyarázó változók ebben az esetben a vevőkapcsolati készpénzmentességet leíró dummy változó, valamint a 2016-os éves árbevételt és a vállalkozás fő tevékenységét kategorizáló dummy változók (referenciaként a legnagyobb elemszámú csoportot felhasználva).

\section{2. táblázat}

A KKV-szektor és a mikrovállalkozások készpénzmentességét magyarázó regressziók becsült együtthatói

\begin{tabular}{|c|c|c|c|}
\hline \multicolumn{2}{|l|}{ KKV-szektor } & \multicolumn{2}{|l|}{ Mikrovállalkozások } \\
\hline Vevőkapcsolataiban készpénzmentes & $2,17^{*}$ & Vevőkapcsolataiban készpénzmentes & $2,26^{*}$ \\
\hline \multicolumn{2}{|l|}{ 2016-os árbevétel (200-500 millió Ft) } & \multicolumn{2}{|l|}{ 2016-os árbevétel (0-25 millió Ft) } \\
\hline 0-100 millió Ft & 0,28 & 25-50 millió Ft & $0,58^{*}$ \\
\hline 100-200 millió Ft & 0,00 & 50-100 millió Ft & 0,2 \\
\hline 500-1000 millió Ft & $-0,01$ & 100 millió Ft felett & $-0,13$ \\
\hline 1000 millió Ft felett & $0,81^{*}$ & \multicolumn{2}{|l|}{ Vállalkozás fő tevékenysége (Egyéb) } \\
\hline \multicolumn{2}{|l|}{ Vállalkozás fő tevékenysége (Egyéb) } & Építőipar & $-1,24 *$ \\
\hline Építőipar & $-0,82 *$ & Kereskedelem & $-0,27$ \\
\hline Kereskedelem & $0,71 *$ & Feldolgozóipar & $-0,29$ \\
\hline Feldolgozóipar & 0,13 & Konstans & $-1,30 *$ \\
\hline Konstans & $-1,53^{*}$ & $N$ & 487 \\
\hline $\mathrm{N}$ & 477 & $\mathrm{R}^{2}$ & 0,20 \\
\hline $\mathrm{R}^{2}$ & 0,19 & & \\
\hline
\end{tabular}


A 2. táblázatban olvasható logisztikus regressziókban szereplő becsült együtthatók log-odds rátaként értelmezhetőek, vagyis azt mutatják meg, hogy az adott tulajdonság megléte a referenciacsoporthoz képest milyen mértékben növeli (pozitív együttható esetén), vagy csökkenti (negatív együttható esetén) a beszállítók felé történő készpénzmentesség esélyrátáját. Megfigyelhető tehát, hogy a vevők irányában készpénzmentes vállalatokra nagyobb mértékben teljesül, hogy beszállítóik felé is elektronikusan teljesítik tranzakcióikat, továbbá egy bizonyos mértékig a nagyobb árbevételű vállalkozásokra is inkább jellemző a készpénzmentesség. Fontos emellett, hogy a készpénzmentesség és a vállalkozás fő tevékenysége között is kimutatható szignifikáns összefüggés: az építőipar szereplőire kevésbé jellemző a készpénz elhagyása, míg a kereskedelemmel foglalkozó kis- és középvállalkozások esetén gyakoribb az elektronikus fizetések kizárólagos alkalmazása.

A fentiek mellett indokoltnak tartottuk a készpénzes bérfizetés jellemzőinek vizsgálatát is, mivel ez áttételesen a lakossági fizetési szokásokat is befolyásolhatja, megértése különösen fontos szerepet játszhat a készpénz hazai gazdaságban betöltött szerepének feltérképezésében. Az ehhez becsült regresszió függő változója a készpénzes bérfizetések százalékos aránya, magyarázó változói pedig a készpénzhasználat aránya a beszállítói kapcsolatokban és a vállalkozás 2016-os éves árbevételét, valamint fő tevékenységét kategorizáló dummy változók (referenciaként a legnagyobb elemszámú csoportot felhasználva). A VIF-együtthatók valamennyi változó esetén 2 alattiak, így a modellben nincs jelen multikollinearitás.

\begin{tabular}{|c|c|}
\hline \multicolumn{2}{|c|}{$\begin{array}{l}\text { 3. táblázat } \\
\text { A KKV-szektor készpénzes bérfizetését magyarázó regresszió együtthatói }\end{array}$} \\
\hline \multicolumn{2}{|l|}{ KKV-k } \\
\hline Készpénzes fizetés aránya a beszállítói kapcsolatokban (\%) & $0,30 *$ \\
\hline \multicolumn{2}{|l|}{$\begin{array}{l}\text { 2016-os árbevétel } \\
\text { (200-500 millió Ft) }\end{array}$} \\
\hline 0-100 millió Ft & $15,57^{*}$ \\
\hline 100-200 millió Ft & 3,10 \\
\hline 500-1 000 millió Ft & $-5,53$ \\
\hline 1000 millió Ft felett & $-11,91^{*}$ \\
\hline \multicolumn{2}{|l|}{ Vállalkozás fő tevékenysége (Egyéb) } \\
\hline Építőipar & $8,71^{*}$ \\
\hline Kereskedelem & 1,53 \\
\hline Feldolgozóipar & 0,97 \\
\hline Konstans & $12,50 *$ \\
\hline $\mathrm{N}$ & 469 \\
\hline $\mathrm{R}^{2}$ & 0,18 \\
\hline
\end{tabular}


A 3. táblázatban szereplő együtthatók megmutatják, hogy a KKV-szektorban a beszállítói tranzakciókban készpénzt preferáló vállalkozások a munkabéreket is nagyobb arányban fizetik készpénzben, a kisebb árbevétellel rendelkező vállalatokra pedig különösen jellemző a készpénzes bérfizetés. Megfigyelhető továbbá összefüggés a vállalkozások fö tevékenységével is: az építőiparral foglalkozó vállalatok bérköltségeik nagyobb hányadát teljesítik készpénzben. A mikrovállalkozások esetén nem mutatható ki szignifikáns kapcsolat a készpénzes bérfizetés és egyéb, általunk vizsgált jellemzők között.

\section{Főbb következtetések}

A tanulmány bemutatta a magyarországi mikro-, kis- és középvállalkozások körében végzett exploratív kutatás eredményeit, amelynek fókuszában a vállalkozások által követett készpénzhasználati gyakorlat feltérképezése, valamint a fizetési magatartásuk megismerése állt. A kutatási eredményeket - ahol az módszertanilag megalapozottnak bizonyult - összevetettük a hasonló tárgykörben 2013-ban végzett kutatás eredményeivel annak érdekében, hogy elemezzük a vállalkozások magatartásának változását a készpénzhasználat, s ehhez kötődően az üzleti kapcsolataikban alkalmazott fizetési magatartás terén. A tanulmány legfontosabb kutatási eredményei, következtetései az alábbiak:

- A magyarországi mikro, kis-, és középvállalkozások körében a legtipikusabb fizetési mód a banki átutalás, a legtöbben és a leggyakrabban ezt a fizetési módot alkalmazzák az üzleti kapcsolataikban, a beszállítói és a vevői pozíciójukban egyaránt.

- A banki átutalások egyértelmú dominanciája ellenére kijelenthető, hogy a magyarországi KKV-k és mikrovállalkozások körében - föként az alacsonyabb értékü, valamint az 500000 forintot meghaladó tranzakciók esetén - a készpénzhasználat továbbra is erősen jelen van, s az elmúlt négy évben annak szerepe, jelentősége nem csökkent.

- A készpénzmentes infrastruktúra dinamikus fejlődése ellenére a KKV-k készpénzhasználati gyakorlatában egyes területeken kedvezötlen irányú elmozdulás tapasztalható a 2013-ban történt adatfelvételhez képest: megnőtt a beszállítói kapcsolataikban készpénzt használó vállalkozások aránya, valamint növekedés tapasztalható a nagy összegú készpénzes tranzakciókat alkalmazó vállalkozások számában is, mind a beszállítói, mind a vevői kapcsolatok esetén. Ugyanakkor a regresszióelemzés igazolta azt a kezdeti intuíciónkat, hogy a vállalatméret növekedésével a készpénzhasználat csökken.

- A B2B kapcsolatokban alkalmazott készpénzes fizetés mellett kiemelendő, hogy a megkérdezett vállalkozások - különösen a mikrovállalatok - körében a készpénz- 
es munkabérfizetés mértéke sem elhanyagolható, amely a B2C kapcsolatokban is további készpénzhasználatot generál.

- A készpénzhasználat okaként a vállalkozások közül legtöbben a kis értéknagyságot jelölték meg, de ennek némileg ellentmond a nagyobb értékű készpénzes tranzakciók arányának növekedése. A felmérés eredményéből sokkal inkább arra lehet következtetni, hogy a készpénz alkalmazása egyfajta mélyen gyökerező attitüdkérdés a vállalkozások müködésében. Sokan megszokásból használják, illetve a helyszíni fizetések lebonyolításának még mindig ez a legegyszerűbb eszköze. Így a - jellemzően a vevők irányából érkező - készpénzes bevételek a vállalkozások üzleti kapcsolatain „akadálymentesen” haladnak tovább, és csak részben, illetve többszöri megfordulást követően érkeznek meg valamelyik vállalkozás bankszámlájára.

- A fizetési magatartás vizsgálata (fizetési fegyelem, határidők betartása, lejárt és behajthatatlan követelések értékének változása) terén feltárt kutatási eredmények egyértelműen arra mutatnak rá, hogy a KKV-szektorban jelentősen javult a vállalkozások üzleti környezete és ezzel együtt a fizetési fegyelem. Ez az elmozdulás a KKV-szektor múködőképessége és növekedési potenciálja szempontjából egyértelmű pozitív üzenet. Egyben azt is jelzi, hogy a gazdasági válság után, az erősen jelen lévő vállalkozások közötti bizalomhiány enyhült, és ennek jelei a vállalkozások fizetési fegyelmében is tetten érhetők. Ma már az elsősorban vevői kapcsolatokban tapasztalható bizalomhiány jóval kevésbé indokolja a rövid fizetési határidők és a készpénz alkalmazását a KKV-k között.

- A mikro-, kis- és középvállalkozások banki kapcsolataikban nagyon erősen lojálisak, szinte alig váltanak számlavezető pénzintézetet. Pozitív elmozdulás, hogy a négy évvel ezelötti állapothoz képest a KKV-k jóval nyitottabbak az elektronikus fizetési megoldások iránt. A készpénzt használó vállalkozások többsége csökkentené készpénzhasználatát, ha az elektronikus fizetési lehetőségek, valamint a kapcsolódó banki szolgáltatások a jelenleginél olcsóbban, rugalmasabban, az igényeikhez még inkább igazodó módon állnának rendelkezésükre (az elektronikus fizetési megoldások költségei csökkentésének hatására több mint kétszer annyian mérsékelnék a készpénzhasználatukat, mint a készpénzes tranzakciók költségei emelésének hatására), adataink azonban arra engednek következtetni, hogy jóval kevesebben vannak azok, amelyek ennek érdekében bankváltásra is hajlandók.

- A kutatási eredmények alapján valószínűsíthető, hogy a vállalkozások részéről jelentős igény mutatkozna széleskörüen használható, azonnali, és alacsony költségekkel járó elektronikus fizetési megoldások bevezetésére, melyet olyan szituációkban is alkalmazhatnának, melyekben jelenleg a készpénzes fizetés jelenti az egyetlen valós alternatívát. Ezt az is megerősíti, hogy a napon belüli átutalás 
bevezetésével a vállalkozások negyede tudta készpénzes forgalmának egy részét elektronikus átutalással felváltani.

- A tranzakciós illeték és a vállalkozások készpénzhasználata között nincs kimutatható közvetlen összefüggés, de az illeték közvetett módon vélhetően szerepet játszik abban, hogy a vállalkozások magasnak érzik banki pénzforgalmi költségeiket. Ennek további következménye lehet, hogy a vállalkozásokhoz bevételként érkező készpénz a beszállítói kapcsolatokban kerül további felhasználásra.

- A KKV-szektor fizetési szokásait az elkövetkező években akár jelentős mértékben is átalakíthatja egyrészt a 2018. július 1-jén hatályba lépett „e-számlázás”, vagyis a NAV felé történő kötelező, 24 órán belüli adatszolgáltatás az elektronikusan kiállított számlákról, másrészt pedig az MNB döntése által a GIRO Zrt. létrehozásában 2019 második felére a belföldi fizetési forgalomban megvalósuló azonnali fizetési rendszer infrastruktúra, mely az év minden napján 5 másodpercen belül megvalósuló tranzakciókat ígér.

\section{Felhasznált irodalom}

Bajada, C. - Schneider, F. (Eds.) (2005): Size, Causes and Consequences of the Underground Economy: An International Perspective. Ashgate, Aldershot, United Kingdom.

Banai Ádám - Körmendi Gyöngyi - Lang Péter - Vágó Nikolett (2016): A magyar kis- és középvállalati szektor hitelkockázatának modellezése. MNB-tanulmányok 123. http://www. mnb.hu/letoltes/mnb-tanulmanyok-123.pdf. Letöltés ideje: 2018. január 18.

Bethlendi András - Végh Richárd (2014): Közösségi finanszírozás - valós lehetöség-e a hazai kisvállalatok számára? Hitelintézeti Szemle, 13(4): 102-126. http://www. hitelintezetiszemle.hu/letoltes/5-bethlendi-vegh-2.pdf

Bódi-Schubert Anikó (2014): Bizalom és fizetési magatartás a kis- és középvállalatok üzleti kapcsolataiban. MNB-tanulmányok 110. http://www.mnb.hu/letoltes/mt110-vegleges. pdf. Letöltés ideje: 2018. január 12.

Burkart, M. - Ellingsen, T. (2004): In-Kind Finance: A Theory of Trade Credit. American Economic Review, 94(3): 569-590. https://doi.org/10.1257/0002828041464579

Esselink, H. - Hernández, L. (2017): The use of cash by households in the euro area. ECB Occasional Paper Series, No. 201. https://www.ecb.europa.eu/pub/pdf/scpops/ecb.op201. en.pdf. Letöltés ideje: 2018. január 18.

Havran Dániel - Kerényi Péter - Víg Attila (2017): Szállitói finanszírozás vagy bankhitelek? A magyar vállalatok 2010 és 2015 közötti tanulságai. Hitelintézeti Szemle, 16(4): 86-121. http://doi.org/10.25201/HSZ.16.4.86121 
Ilyés Tamás - Takács Kristóf - Varga Lóránt (2014): A pénzforgalmi szolgáltatások dijainak és a pénzforgalom szerkezetének alakulása a pénzügyi tranzakciós illeték bevezetését követően. MNB-szemle, (Március): 40-48. https://www.mnb.hu/letoltes/ilyes-takacsvarga-1.pdf. Letöltés ideje: 2018. január 15.

Ilyés Tamás - Varga Lóránt (2015): Mutasd, mivel fizetsz, megmondom, ki vagy A pénzforgalmi szokásokat befolyásoló szociodemográfiai tényezők. Hitelintézeti Szemle, 14(2): 26-61. http://www.hitelintezetiszemle.hu/letoltes/2-ilyes-varga.pdf

Intrum Justitia (2017): European Payment Report 2017. https://www.ijcof.fr/globalassets/ countries/france/pdfs/epr-2017.pdf. Letöltés ideje: 2018. január 12.

KSH (2017): A kis- és középvállalkozások helyzete hazánkban, 2016. http://www.ksh.hu/ docs/hun/xftp/idoszaki/pdf/kkv16.pdf. Letöltés ideje: 2018. január 12.

McGuiness, G. - Hogan, T. - Powell, R. (2018): European trade credit use and SME survival. Journal of Corporate Finance, 49 (April): 81-103. https://doi.org/10.1016/j. jcorpfin.2017.12.005

MNB (2018): Fizetési rendszer jelentés, 2018. https://www.mnb.hu/letoltes/mnb-fizetesirendszer-jelentes-2018-hun.pdf. Letöltés ideje: 2018. június 20.

Rogoff, K. (1998): Blessing or curse? Foreign and underground demand for euro notes. Economic Policy, 13(26): 261-303. https://doi.org/10.1111/1468-0327.00033

Semjén András - Tóth István János - Medgyesi Márton - Czibik Ágnes (2009): Adócsalás és korrupció - lakossági érintettség és elfogadottság. In: Semjén András - Tóth István János (Eds.): Rejtett gazdaság - Be nem jelentett foglalkoztatás és jövedelemeltitkolás kormányzati lépések és a gazdasági szereplők válaszai, MTA KTI, Budapest, pp. 228-258.

Tu, T. - Salmon, C. (2016): Uses of Cash and Electronic Payments. https://assets.publishing. service.gov.uk/government/uploads/system/uploads/attachment_data/file/557331/ Uses_of_Cash_and_Electronic_Payment.pdf. Letöltés ideje: 2018. január 16. 


\section{Melléklet}

\section{A magyarországi mikro-, kis- és középvállalkozások fizetési szokásai kutatás során alkalmazott kvantitatív kérdőív szerkezete}

1. Cégdemográfiai kérdések (a vállalkozás fö tevékenységi köre, alkalmazotti létszám, nettó árbevétel), a válaszadó pozíciója a vállalkozásnál

2. Fizetési szokások a beszállítói kapcsolatokban

- A vállalkozás által alkalmazott fizetési módok a beszállítói kapcsolatokban (feleletválasztás, több válasz is megjelölhető: készpénzfizetés; átutalás; kártyás fizetés; egyéb, éspedig)

- A vállalkozás által alkalmazott egyes fizetési típusok előfordulási aránya (az összes fizetés százalékában megadva)

- Jellemzően mekkora az egyes készpénzes fizetési múveletek átlagos értéke (feleletválasztás: 50000 Ft alatti; 50-100 000 Ft közötti; 100 001-500 000 Ft közötti; 500000 Ft feletti)

- Milyen okai vannak a vállalkozásnál a készpénz alkalmazásának a beszállítói kapcsolatokban (feleletválasztás, több válasz is megjelölhető: kis értéknagyság; az áru és a pénz cseréjének egyidejűsége; a helyszíni fizetések csak így bonyolíthatók le; megszokás; a nemfizetéstől való félelem; gyorsaság; olcsóság (alacsony tranzakciós költség); így elkerülhető a számlaadás; beszállítói preferencia, így szeretik lebonyolítani a tranzakciókat; egyéb, éspedig)

- Hány napos fizetési határidő alkalmazása jellemző a beszállítókkal kötött üzleti tranzakciók során (feleletválasztás: a teljes vételár előre fizetését követelik meg; azonnali, egyidejű készpénzes fizetés; 8 nap, vagy azon belüli fizetési határidő; 8 és 30 nap közötti fizetési határidő; 30 napos fizetési határidő; 30 és 60 nap közötti fizetési határidő; 60 és 90 nap közötti fizetési határidő; 90 napon túli fizetési határidő)

- Van-e jelenleg lejárt tartozása a beszállítóival szemben, és ha igen, az összesen nagyságrendileg mekkora összeget tesz ki? (feleletválasztás: 1 millió Ft alatti; 1 és 5 millió Ft közötti; 5 és 10 millió Ft közötti; 10 millió Ft-ot meghaladó)

\section{Fizetési szokások a vevői kapcsolatokban}

- A vállalkozás által alkalmazott fizetési módok a vevői kapcsolatokban (feleletválasztás, több válasz is megjelölhető: készpénzfizetés; átutalás; kártyás fizetés; egyéb, éspedig)

- A vállalkozás által alkalmazott egyes fizetési típusok előfordulási aránya (az összes fizetés százalékában megadva) 
- Jellemzően mekkora az egyes készpénzes fizetési múveletek átlagos értéke (feleletválasztás: 50000 Ft alatti; 50-100 000 Ft közötti; 100 001-500 000 Ft közötti; 500000 Ft feletti)

- Milyen okai vannak a vállalkozásnál a készpénz alkalmazásának a vevői kapcsolatokban (feleletválasztás, több válasz is megjelölhető: kis értéknagyság; az áru és a pénz cseréjének egyidejüsége; a helyszíni fizetések csak így bonyolíthatók le; megszokás; a nemfizetéstől való félelem; gyorsaság; olcsóság (alacsony tranzakciós költség); így elkerülhető a számlaadás; vevői preferencia, így szeretnek fizetni; egyéb, éspedig)

- Jellemzően hány napos fizetési határidőt alkalmaznak a vevők felé történő értékesítéskor (feleletválasztás: a teljes vételár előre fizetését követelik meg; azonnali, egyidejú készpénzes fizetés; 8 nap, vagy azon belüli fizetési határidő; 8 és 30 nap közötti fizetési határidő; 30 napos fizetési határidő; 30 és 60 nap közötti fizetési határidő; 60 és 90 nap közötti fizetési határidő; 90 napon túli fizetési határidő)

- Alkalmaznak-e eltérő fizetési feltételeket régi és új vevők esetén, és ha igen, milyen módon? (feleletválasztás: a fizetési feltételek az új vevők számára szigorúbbak; a fizetési feltételek az új vevők számára enyhébbek)

- Új vevők esetében a fizetési feltételek meghatározásánál szerepet játszanak-e a következő szempontok (igen/nem, több is megjelölhető): az új vevő piaci hírneve; követelésminősítő cégek ajánlásai; a fizetési feltételek tárgyalási alapot képeznek; egyéb, éspedig

- Előfordult-e az elmúlt három év során, hogy változtattak a fizetési feltételeken egy meglevő vevőkapcsolatukban (igen/nem), és ha igen, milyen módon (feleletválasztás: jellemzően szigorították a feltételeket; jellemzően enyhítették a feltételeket)

- Mennyire jellemző, hogy figyelembe vesznek piaci követelésminősítő, adósminősítő vállalkozásoktól származó értékelést a vevők számára ajánlott fizetési feltételeiknek a kialakításakor? (feleletválasztás: rendszeresen figyelembe veszik ezeket; alkalmanként vagy szükség esetén veszik ezeket figyelembe; nem használnak ilyen értékeléseket)

- Van-e jelenleg lejárt vevőkövetelése (van/nincs), és ha van, összesen nagyságrendileg mekkora összeget tesz ki (feleletválasztás: 1 millió Ft alatti; 1 és 5 millió Ft közötti; 5 és 10 millió Ft közötti; 10 millió Ft-ot meghaladó)

- Volt-e behajthatatlan vevőkövetelése az elmúlt három évben (volt/nem volt), és ha volt, összesen nagyságrendileg mekkora összeget tett ki (feleletválasztás: 1 millió Ft alatti; 1 és 5 millió Ft közötti; 5 és 10 millió Ft közötti; 10 millió Ft-ot meghaladó) 
4. Közüzemi számlák és a munkabér fizetésére jellemző fizetési szokások

- Milyen fizetési módok jellemzők a vállalkozásnál a közüzemi számlák kiegyenlítésére (feleletválasztás, több válasz is megjelölhető: készpénzfizetés; készpénzátutalási megbízás („sárga csekk”); átutalás; csoportos beszedési megbízás; egyéb)

- Nagyságrendileg mekkora hányadát fizetik az alkalmazottak munkabérének készpénzfizetéssel és átutalással (százalékos megoszlás, kizárólag a munkabérre vonatkozóan, cafeteria, bérlet, egyéb juttatás nélkül, mozgóbér esetén átlagos hónapot nézve)

5. Szabályozói intézkedések (napon belüli átutalás, tranzakciós illeték) hatása, a készpénzhasználat csökkentésének ösztönzői

- A napon belüli átutalás elérhetővé válásának a vállalkozás szempontjából van-e érzékelhető jelentősége (van/nincs), és ha van, akkor a válaszadó véleménye szerint a következő állítások igazak-e a vállalkozás szempontjából (igaz/nem igaz): egyszerúbbé vált a fizetési műveletek lebonyolítása, kontrollálhatósága; likviditási, költségtakarékossági előnyök származnak belőle; kényelmesebbé és gyorsabbá tette a banki átutalások lebonyolítását; készpénzes forgalmat tudott elektronikus átutalásokkal felváltani; egyéb, éspedig

- Változtak-e az elmúlt 1-3 évben a vállalkozás pénzintézeti számlavezetési költségei (igen/nem), és ha igen, hogyan (feleletválasztás: kismértékben emelkedtek; nagymértékben emelkedtek; kismértékben csökkentek; nagymértékben csökkentek)

- A tranzakciós illeték befolyásolta-e a vállalkozás által alkalmazott fizetési gyakorlatot (igen/nem), és ha igen, a válaszadó véleménye szerint hogyan (feleletválasztás, több válasz is megjelölhető: megpróbálják összevonni a partnerek felé indított egyes elektronikus fizetéseket az illetékfizetés felső korlátjának elérése érdekében; az elektronikus fizetések korábbinál nagyobb arányát bonyolítják le külföldi bankon keresztül; olyan banki szolgáltatást választottak, ahol a pénzintézet átvállalja a tranzakciós illeték egy részét; több kimenő fizetést bonyolítanak le elektronikus helyett készpénzes módon; több bejövő fizetés érkezik elektronikus helyett készpénzes módon; egyéb, éspedig)

- A felsoroltak ösztönzést jelentenének-e a vállalkozás számára a készpénzes múveletek elektronikus fizetési megoldásokkal történő helyettesítésére (igen/nem, több válasz is megjelölhető: a vállalatok közötti fizetési fegyelem növekedése; az elektronikus fizetési megoldások költségének (pl. kereskedői jutalék, számlavezetési díj, tranzakciós díj) csökkenése; a készpénzes tranzakciók költségének emelkedése; az elektronikus banki szolgáltatások bővülése, rugalmasabbá válása; egyéb, éspedig; nem tartja fontosnak a készpénzmentesítést) 


\section{A vállalkozás hitelintézeti kapcsolatai, bankválasztás, bankváltás}

- Váltottak-e számlavezető pénzintézetet az elmúlt 1-3 évben (igen/nem), és ha igen, mi volt ennek a fö oka (feleletválasztás: költségtakarékosság; kényelmesebb, vállalati igényekre szabott kiszolgálás; kedvezőbb pénzügyi szolgáltatáscsomag (pl. számlavezetési feltételek); elégedetlenség a korábbi pénzintézettel; ügyfélkapcsolat, kiszolgálás nem volt kielégítő a korábbi pénzintézetnél; közelség; nyitva tartás; egyéb, éspedig)

- Ha a váltásnak az előbb említett fő oka mellett volt további oka is, mi volt az (feleletválasztás: költségtakarékosság; kényelmesebb, vállalati igényekre szabott kiszolgálás; kedvezőbb pénzügyi szolgáltatáscsomag (pl. számlavezetési feltételek); elégedetlenség a korábbi pénzintézettel; ügyfélkapcsolat, a kiszolgálás nem volt kielégítő a korábbi pénzintézetnél; közelség; nyitva tartás; egyéb, éspedig)

- A számlavezető pénzintézet kiválasztásakor több mindennek lehet jelentősége. A felsorolt állítások közül melyikkel ért leginkább egyet: csak olyan pénzintézetet választok, amelynek van a székhelyemhez/telephelyemhez közeli fiókja; a fiókhálózat elérhető közelsége akár a számlavezetési díjaknál is fontosabb számomra; ha kedvezőbb banki dijakat vagy szolgáltatást kapok, akkor hajlandó vagyok távolabbi településen/kerületben levő bankfiókkal kapcsolatot fenntartani; csak olyan pénzintézetet választok, amelyikkel zökkenőmentesen tudom fenntartani a kapcsolatot; nincs számomra jelentősége a bankfióknak, többségében elektronikusan intézem a számlamúveleteimet

- Ha felkeresi vállalkozása számlavezető bankfiókját, akkor a felsoroltak közül jellemzően milyen típusú ügyleteket bonyolít le (feleletválasztás, több válasz is megjelölhető: készpénz ki- és befizetése; valutapénztári szolgáltatások igénybevétele; papíralapú átutalási megbízások benyújtása; egyéb számlamúveleti tevékenység (pl. jogosultságok kezelése); megtakarításokkal kapcsolatos ügyintézés; hitelügyintézés) 